\title{
Osmanlı Eczacı İttihad Cemiyeti’nin (Union Pharmaceutique Ottomane) Kuruluşu ve Nizamnamesine Göre Yapısı
}

\section{Ottoman Pharmacists' Association (Union Pharmaceutique Ottomane): Its Establishment and Organization as Defined in its Regulations}

\author{
Eyüp Talha Kocac1k ${ }^{1}$ (D)
}

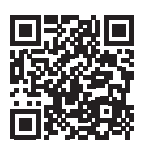

'Eczacı, Kocacık Eczanesi, Adapazarı, Sakarya, Türkiye

\section{ORCID: E.A. 0000-0003-4197-8470}

Sorumlu yazar/Corresponding author: Eyüp Talha Kocacık,

Eczacı, Kocacık Eczanesi, Adapazarı, Sakarya, Türkiye

E-posta/E-mail: eyuptalha@kocacik.com

Başvuru/Submitted: 11.09 .2021

Revizyon Talebi/Revision Requested:

07.10. 2021

Son Revizyon/Last Revision Received:

20.10.2021

Kabul/Accepted: 20.20 .2021

Atıf/Citation: Kocacık, Eyüp Talha. “Osmanlı Ittihad Cemiyeti'nin (Union Pharmaceutique Ottomane) Kuruluşu ve Nizamnamesine Göre Yapısı." Osmanlı Bilimi Araştırmaları 23, 1 (2022): 137-199.

https://doi.org/10.26650/oba.994231
ÖZ

Osmanlı eczacılarının mesleki örgütlenmesinin 6 Kasım 1863 tarihinde Société de Pharmacie de Constantinople (Cemiyet-i Eczacıyan der Asitâne-i Aliyye, Dersaadet Eczacı Cemiyeti) isimli cemiyetin kurulmasıyla başladığı kabul edilmektedir. Bu yıllarda, ülkedeki eczacıların büyük çoğunluğunun gayrimüslim olması nedeniyle, bu cemiyet ve daha sonra kurulan eczacılık cemiyetleri gayrimüslim eczacılardan oluşmuştur. Dönemin evrensel tıp ve eczacılık dilinin Fransızca olmasının etkisiyle, cemiyetler Fransızca isimleriyle tanındıkları gibi, yazışma ve toplantılarının sunum dili de Fransızca olmuştur. Eczacı cemiyetleri, 1908'de, İkinci Meşrutiyet'in ilânından sonra, farklı bir safhaya geçmiştir. Bu dönemde birden fazla eczacılık cemiyeti kurulduğu gibi, "millet" esasına dayanan cemiyetler de ortaya çıkmıştır. Bunlardan biri, 20 Ağustos 1908 tarihinde üyelerinin çoğunluğu Türk ve Müslüman olan eczacılar tarafından İstanbul'da kurulan Osmanlı Eczacı İttihad Cemiyeti'dir. Bu cemiyetin ismi, yazışma, yayın ve toplantı dili Türkçe olduğu gibi, nizamnamesi de Türkçe olarak kalem alınmıştır. Dolayısıyla bu cemiyet, şimdiki bilgilerimiz ışığında, Meşrutiyet'in ruhuna uygun, aynı zamanda Osmanlı milletlerinin ittihadını amaçlayan bir eczacılık cemiyetidir. Bu makalede, cemiyetin bugüne kadar bilinmeyen nizamnamesi ve diliçi çevirisi verilecek ve bu nizamname doğrultusunda cemiyetin kuruluş süreci, yapısı, özellikleri ve kurucuları incelenecektir. Amaç, Türk eczacılık tarihi çalışmalarına katkı sağlamaktır.

Anahtar sözcükler: Osmanlı Eczacı İttihad Cemiyeti, mesleki cemiyetler, Türk eczacılık tarihi, Osmanlı İmparatorluğu, eczacı birlikleri, eczacılık cemiyetleri

\section{ABSTRACT}

The first association of Ottoman pharmacists known as the Société de Pharmacie de Constantinople (Istanbul Society for Pharmacists), was inaugurated on November 6, 1863. Most Ottoman pharmacists in these years were from the non-Muslim millets of the Empire, which was reflected in the membership profile of the Society. French was the universal scientific 
language, and pharmacists' society conducted its session in this language, which was also used in correspondence and publications. Professional societies were re-formed after 1908, in the Second Constitutional period. Associations were promoted and the number of associations multiplied; and pharmacists from all millets established new societies. On August 20, 1908, a society was established with the initiative of Turkish pharmacists in Istanbul, under the name of Osmanlı Eczacı Ittihad Cemiyeti (Union Pharmaceutique Ottomane). The union chose to use Turkish language in its sessions and correspondence. Its regulation was published in Ottoman Turkish. Our present knowledge leads us to visualize this pharmacists' society as a creation of this era characterized by the progress and union within the Empire. This article introduces the society's original regulation with transcription. These regulations also shed light on the society's foundation and functions. Biographies of its first members are also briefly reviewed.

Keywords: Union Pharmaceutique Ottomane, professional societies, history of Turkish pharmacy, Ottoman Empire, pharmacists' associations, pharmaceutical societies

\section{Eczacıların İkinci Meşrutiyet Öncesinde Kurdukları Mesleki Cemiyetlere Kısa Bakış}

Osmanlı eczacıları, mesleki örgütlenmelerine 6 Kasım 1863 tarihinde İstanbul'da kurdukları Société de Pharmacie de Constantinople (Cemiyet-i Eczaciyan der Asitâne-i Aliyye, Dersaadet Eczacı Cemiyeti) isimli cemiyetle başlamışlardır. Cemiyet kurucularının hepsinin muhtemelen gayrimüslim eczacılardan oluşması ve dönemin evrensel dilinin Fransızca olması sebebiyle cemiyetin ismi, yazışmaları ve toplantı dili Fransızcadır. Société de Pharmacie de Constantinople 1868 yllına kadar faaliyet göstermiştir. On bir yıllık bir aranın ardından 9 Haziran 1879 tarihinde eczacı-kimyager Charles Bonkowski Paşa'nın öncülüğünde 210 eczacı bir araya gelerek Société de Pharmacie de Constantinople (Cemiyet-i Eczacıyan der Asitâne-i Aliyye) tekrar kurulmuş ve Charles Bonkowski cemiyet başkanı seçilmiştir. ${ }^{1}$ Cemiyetin ikinci kuruluşunda 210 üye eczacının sadece ikisini Türk eczacılar, Numan Bey ve Rıza Efendi oluşturmuştur.

İstanbul'da bulunan bir grup Osmanlı eczacıs1, ihtiyacı olan eczacılara veya ailelerine maddi ve manevi yardım yapmak amaciyla 25 Ocak 1891 tarihinde Association Pharmaceutique de Secours Mutuel de Constantinople (Mütekabil Sigorta, İstanbul Eczacıları Karşılıklı Yardım Birliği) ismiyle bir cemiyet kurmuşlardır. İkinci Meşrutiyet'in ilanından bir yıl önce, 1907 yılında yabancı uyruklu eczacılar tarafindan İstanbul'da Association des Pharmaciens Étrangers (Yabancı Eczacılar Birliği) kurulmuştur. Bu birlik sadece yabancı devletlerin elçiliklerince tanınmıştır. ${ }^{2}$

\section{Osmanlı Eczacı İttihad Cemiyeti’nin Kurulmasına Giden Süreç}

1863 yılında örgütlenerek mesleki dayanışma sağlamaya çalışan eczacıların, İkinci Meşrutiyet'in ardından birden fazla cemiyet kurdukları görülür. ' İkinci Meşrutiyet'in ilanının

1 Turhan Baytop, “Osmanlı İmparatorluğu Döneminde Eczacılık Cemiyetleri," Osmanlı İlmî ve Meslekî Cemiyetleri, yay. haz. Ekmeleddin İhsanoğlu (İstanbul: Edebiyat Fakültesi ve IRCICA, 1987) içinde, 145.

2 Turhan Baytop, Türk Eczacılık Tarihi Araştırmaları (İstanbul: Sinangil Matbaas1, 2000), 24, 138. Kurulan bu iki cemiyet ile ilgili bilgilerimiz henüz Baytop'un yazdıklarından öteye gidememiştir.

3 Hekimler arasında da İkinci Meşrutiyet'in etkisiyle kurulan ve farklı özellikler barındıran cemiyetler 
ardından tabir yerindeyse dernekleşme yarışı çerçevesinde Müslüman ve gayrimüslim eczacılar yeni bir meslek cemiyeti kurmak üzere bir araya gelmiştir. 1879'da kurulan ve çalışmaları polis tarafından durdurulan Société de Pharmacie de Constantinople'un (Dersaadet Eczacı Cemiyeti) üyelerinin bir kısmı dönemin önde gelen eczacılarıyla birleşerek Osmanlı Eczacı İttihad Cemiyeti'ni (Union Pharmaceutique Ottomane) kurmuşlardır. ${ }^{4}$ Cemiyet'in kuruluş toplantısı, İstanbul'da 7 Ağustos 1324 (20 Ağustos 1908) tarihinde Haliç’teki Fener gazinosunda yapılmıştır. Millet (dini topluluk) ayrımı yapılmaksızın tüm eczacıların üye olacağı bu cemiyetin bu ilk toplantısında ilaç fiyat tarifesi ile eczacılar ve eczaneler kanunu çalışmalarının yürütülmesi için iki komisyon oluşturulmuştur. ${ }^{5}$ Osmanlı Eczacı İttihad Cemiyeti'nin kurucularının isimleri ve yapılan seçim sonucu aldıkları oylar Tablo 1'de verilmiştir.

Tablo 1. Osmanlı Eczacı İttihad Cemiyeti’nin ilk idare heyetine seçilen eczacılar ve seçimde aldıkları oylar. ${ }^{6}$

\begin{tabular}{|l|c|c|}
\hline GÖREVI & ECZACININ ADI & ALDIĞI OY \\
\hline Reis-i Evvel & Hamdi Bey & 107 \\
\hline Reis-i Sânî & Andrea Myrides Efendi & 62 \\
\hline Âzâ & Othont Cilaciyan Efendi & 73 \\
\hline Âzâ & Edhem Pertev Bey & 62 \\
\hline Âzâ & Mehmed Kazım Bey & 60 \\
\hline Âzâ & Jak (Jacques) Garih Efendi & 58 \\
\hline Âzâ & Hakk1 Bey & 55 \\
\hline Âzâ & (Agop) Maksud Nargileciyan Efendi & 55 \\
\hline Âzâ & Vasilyadis Efendi & 54 \\
\hline Âzâ & Beşir Kemal (Pelin) Bey & 49 \\
\hline Âzâ & (J.M.) Kalikiyopulos Efendi & 46 \\
\hline Âzâ & Sava (Vasil) Nazlığlu & 45 \\
\hline
\end{tabular}

görülmektedir. Etker'in ifadesiyle meşrutiyet, meslek örgütlerini "kristal bir prizma gibi bileşenlerine ayrılmıştır”. Bkz. Şeref Etker, İkinci Meşrutiyetin Tabip Örgütleri (İstanbul: Libra Kitapçılık, 2017), 456. Meşrutiyet'in getirdiği bu cemiyetleşme yarışında İstanbul dışındaki şehirlerde de eczacı cemiyetleri kurulmuştur. 1910 yılında Trabzon'da, Trabzon Osmanlı Eczacılar Cemiyeti; 1910 yılında Samsun'da, Osmanlı Eczacılar İttihad Cemiyeti kurulmuştur. Bkz. Eyüp Talha Kocacık, "İstanbul ve Anadolu Eczanelerinde Mesai Saatleri ve Nöbet Uygulamaları: Bir Tarihçe," Osmanlı Bilimi Araştırmaları 22, 1 (2021): 158-163. Eczacı cemiyetlerinin oluşum süreçlerinde Meşrutiyet'in bu etkisinin bir benzeri de Türkiye Eczacıları Cemiyeti'nin 1954 yllında kapanmasına giden süreçte yaşanmıştır. Cemiyet üyesi eczane sahibi, muavin, asker, ecza deposu ve ecza laboratuvarı sahibi eczacılar cemiyetin oluşturduğu birlik etkisinin zayıflamasının ardından bir bir ayrılarak kendilerine ait cemiyetler kurmaya başlamıştır. Bkz. Eyüp Talha Kocacık, "Türk Eczacıları Birliği’nden Önce Mesleki Örgütlenmenin Kısa Tarihi,” TEB Haberler 7 (2020): 10-11.

4 Baytop, "Osmanlı İmparatorluğu Döneminde Eczacılık Cemiyetleri," 146-147.

5 "Société Pharmaceutique," Le Moniteur Oriental, 25 Ağustos 1908, 3.; Baytop, "Osmanlı İmparatorluğu Döneminde Eczacilık Cemiyetleri," 148-149.

6 Dersaadet Osmanlı Eczacı Ittihat Cemiyeti Nizamnamesi (Dersaadet: Mahmud Bey Matbaası, 1326), 19. Cemiyet nizamnamesinin kapağında "Dersaadet" kelimesi bulunmakla birlikte, cemiyet mühründe ve arşiv belgelerinde "Dersaadet" kelimesi kullanılmamıştır. Nizamnamede bu kelimenin yer alması, cemiyetin İstanbul'da kurulduğunu göstermek amacını taşır. 
Kurulan cemiyetin ilk başkanlığına Eczacı Hamdi Bey seçildiği gibi on iki kişilik idare heyetinden beşini Türk eczacılar, yedisini gayrimüslim eczacılar oluşturmuştur. Türk eczacıların gayretleri ile kurulan bu cemiyetin ilk toplantısına 250'ye yakın eczacının katıldığ 1 ifade edilmiştir. ${ }^{7}$ Fakat kurucuların aldıkları oylara baktığımızda en yüksek oyu alan cemiyet başkanı Hamdi Bey'in 107 oy aldığı görülmektedir. Buradan hareketle toplantıya katılan eczacılar arasında tam bir ittifak sağlanamadığı veya toplantı katılım sayısı olarak verilen 250 sayısının hatalı olabileceği düşünülmektedir. ${ }^{8}$ İlk toplantıda oluşturulan komisyonlar ve o komisyonlara seçilen eczacıların isimleri şöyledir:

Eczacılar ve Eczaneler Kanunu Komisyonu: Hamdi Bey, Pierre Apéry, Léon Fridman Irinéu, Jean Cesar Reboul, Vincent Giannetti [Canzuch], Hasan Rauf [Görgülü] Efendi, Eugène Dellasudda, Jacques Ezekiel Garih, Jean Jurescu, Hüseyin Hüsnü Efendi ve Elias Tchitchekian (Çiçekyan).

İlaç Fiyat Tarife Komisyonu: Jacques Garih, İbrahim Halil Efendi, Tsalikes/Tsaliki, Jean Mavrikides ve raportör olarak Jean Jurescu. ${ }^{9}$

Kurulan cemiyetin 68 maddeden $^{10}$ oluşan nizamnamesi 2 Kasım 1908 tarihinde cemiyet başkanı eczacı Hamdi Bey ve cemiyet genel sekreteri Hakkı Bey'in imzalarıyla Dâhiliye Nezareti'ne sunulmuştur. ${ }^{11}$ Nizamname, resmi makamlarca 2 Ocak 1909 tarihinde onaylanmıştır. Cemiyet merkezi Beyoğlu'nda bir apartmanın alt katında tesis edilmiştir. ${ }^{12}$

7 Farmakoloğ, "Mesleğimizin Türkiye'deki Tarihçesi," Farmakoloğ 3, 7-8 (1933): 697; Eyüp Talha Kocacık, Farmakoloğ Dergisinin Özetli Bibliyografyası ve İncelemesi (İstanbul: Eczacılık Tarihi Araştırma Derneği, 2016), 43.

8 Bu dönemde İstanbul'da 324 eczanenin olduğu ifade edilmektedir. Bkz. Revue Médico- Pharmaceutique 24, 2 (1911): 19 .

9 Baytop, Türk Eczacılık Tarihi Araştırmaları, 24.

10 Cemiyet nizamnamesinde numaralandırmada hata yapılmıştır. Nizamnamede 69 madde gözüktüğü halde toplamda 68 madde bulunmaktadır.

11 Başkanlık Osmanlı Arşivi (BOA). Dâhiliye Mektubî Kalemi (DH. MKT) 2673-3-3, 9 Zilkade 1326 (3 Aralık 1908).

12 Farmakoloğ, "Mesleğimizin Türkiye'deki Tarihçesi," Farmakoloğ 3, 7-8 (1933): 699. 


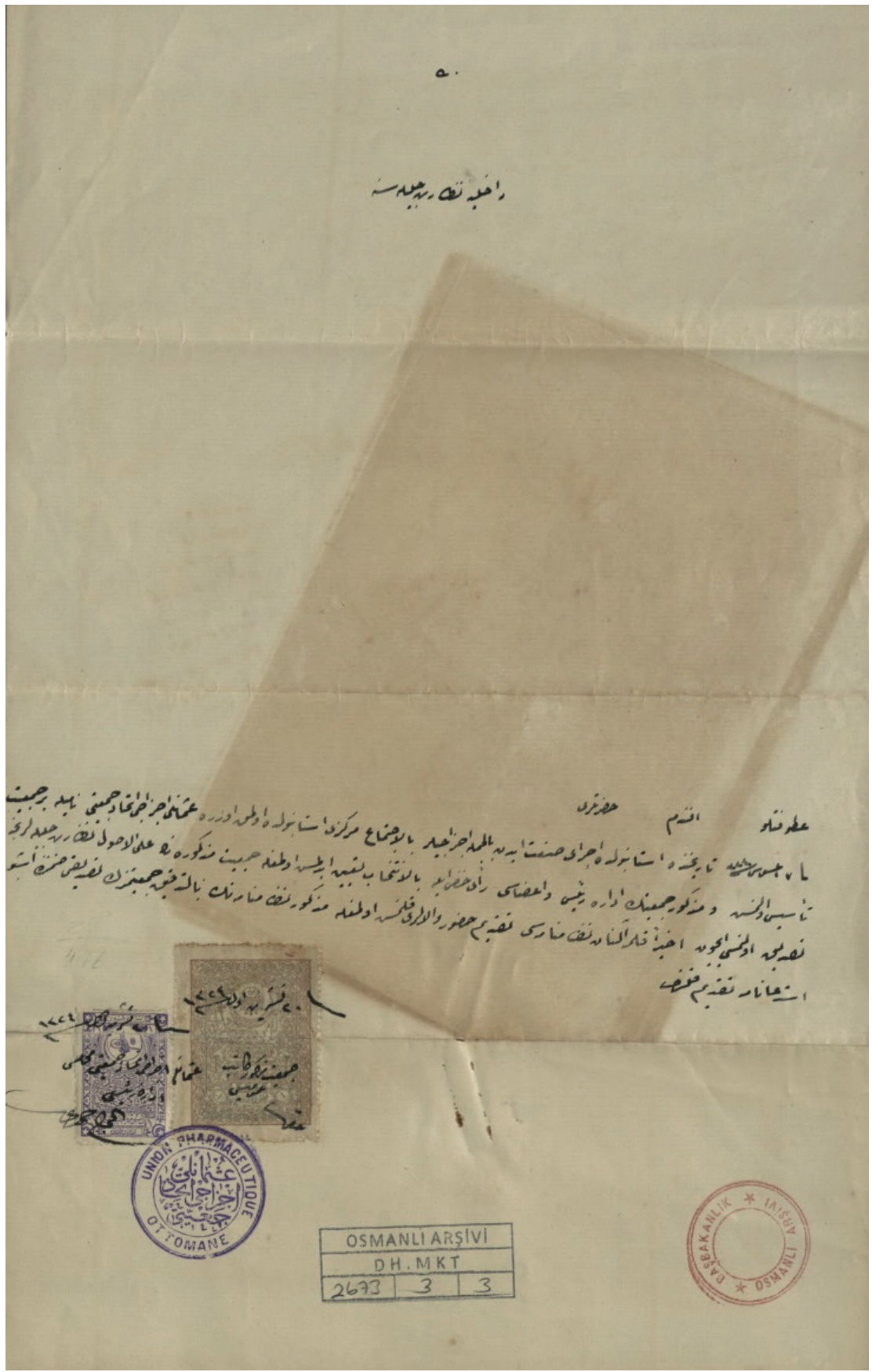

Şekil 1. Osmanlı Eczacı İttihad Cemiyeti’nin Dâhiliye Nezareti’ne verdiği kuruluş dilekçesi BOA. DH. MKT. 2673-3-3, 9 Zilkade 1326 (3 Aralık 1908) 


\section{Dâhiliye Nezâret Celîlesine}

\section{Atûfetlü Efendim Hazretleri}

Fi 7 Ağustos 324 tarihinde İstanbul'da icrâ-yı sanat eden bilcümle eczacılar bil-ictimâ merkezi İstanbul'da olmak üzere Osmanlı Eczacı İttihad Cemiyeti nâmile bir cemiyet tesis olunmuş ve mezkûr cemiyetin idare reisi ve âzâsı rey-i hâzır ile bil-intihab tayin edilmiş olmağla cemiyet-i mezkûrenin alel-usul nezâret-i celîlelerine takdim olunması için ihbaren kalem alınan nizamnâmesi takdim-i huzur-1 vâlâları kılınmış olmağla mezkûr nizamnâmenin bit-tedkik cemiyetimizin tasdiki zımnında işbu istidanâme takdim kılındı.

Fi 20 Teşrin-i evvel 1324 [2 Kasım 1908]

Cemiyet-i mezkûr kâtib-i umûmîsi Hakk1

Fi 20 Teşrin-i evvel 1324 [2 Kasım 1908]

Osmanlı Eczacı İtthad Cemiyeti Meclis-i İdare reisi El-Hac Hamdi

Mühür: Osmanlı Eczacı İttihad Cemiyeti / Union Pharmaceutique Ottomane

Şekil 2. Osmanlı Eczacı İttihad Cemiyeti’nin kuruluş dilekçesinin transkripsiyonu

\section{Cemiyetin Amacı ve Teşkilat Yapısı}

Osmanlı Eczacı İttihad Cemiyeti, İstanbul ve taşradaki üyelerinin meslek haklarını korumayı ve geliştirmeyi amaç edinmiştir. Belirlenen bu amaç, nizamnamenin 2. maddesinde 19 ayrı fikrada ayrıntılı olarak yazılmıştır. Bu kapsamda, eczacılar ve eczaneler kanunu, ilâç fiyat tarifesi, yardımlaşma sandığı, Avrupa' da bulunan meslek cemiyetleriyle ilişki kurmak, eczacılara mahkemelerde yardımcı olmak, ülkede ilaç laboratuvarı ve fabrikası kurmak, eczacılık mesleğinin gelişmesine katkı sunmak ve bu konuda toplantılar yapmak, eczanelere alınacak kalfa ve stajyer öğreniciler için gerekli düzenlemeleri yapmak gibi konular cemiyetin esas amaçları olarak belirlenmiştir.

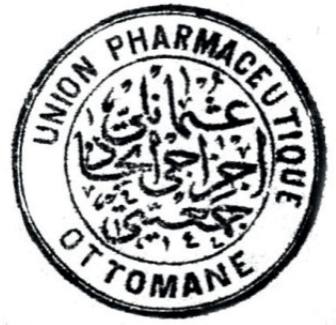

Şekil 3. Osmanlı Eczacı İttihad Cemiyeti'nin mührü Dersaadet Osmanlı Eczaci Ittihat Cemiyeti Nizamnamesi

(Dersaadet: Mahmud Bey Matbaas1, 1326), 19. 
Cemiyet nizamnamesinde üç grup üye sınıflaması yapılmıştır.

Üye: İstanbul sınırlarında ikamet eden diploma sahibi eczacılar.

Muhabir Üye: Osmanlı Devleti içerisinde veya yabancı ülkelerde bulunan diplomalı eczacilar.

Fahri Üye: Osmanlı Devleti içerisinde veya yabancı ülkelerde eczacılık bilimine faydalı iş yapanlar ile cemiyet adına telif eser yazmış olan kişilerdir.

Cemiyetin idare heyeti 12 kişiden oluşur ve üyeler arasından oy çokluğu ve gizli olarak seçilir. İdare heyetindeki görevler şunlardır: Reis (başkan), reis-i sânî (ikinci başkan), kâtib-i umumî (genel sekreter), kâtib-i hususî (oturum sekreteri), hâfız-1 kütub (kütüphane ve arşivci), muhasebeci, sandık emini (veznedar).

İdare heyeti toplantıları her ayın yedinci ve yirmi birinci günlerinde gün doğumundan bir saat sonra cemiyet merkezinde yapılır. Toplantı günü Cuma, Cumartesi, Pazar veya dini bayramlara denk gelirse uygun olan başka bir güne ertelenir. İdare heyeti üyelerinin biri, üç kez üst üste toplantıya katılmazsa idare heyetinden çıkarılır ve yerine başka bir üye seçilir.

Cemiyetin çalışmalarının yapılması için bir merkez tesis edilmesi planlanmış olup bu merkezin içerisinde üye eczacıların kullanabileceği bir kütüphane ve bir toplantı salonu yapılacaktır. Kütüphane her Cuma, Cumartesi ve Pazar günleri gün doğumundan itibaren sadece dört saatliğine üyelere açık tutulacaktır. Üyeler, dipkoçanlı bir makbuz karşılığında kütüphaneciden kitap alabilecektir.

Cemiyetin kasasındaki meblağ 20 (altın) lirayı geçerse para Osmanlı Bankası'na makbuz karşılığında yatırılacaktır. Cemiyet reisi bir yıl içinde 10 lirayı idare heyetine belgelemek kaydıyla harcayabilir.

Cemiyetin seçim ve toplantılarına sadece üyeler katılabilir. Cemiyete üye olmak için cemiyet üyesi iki kişinin önerisi ve genel kuruluda oy çokluğu gerekmektedir. Üyelere cemiyet başkanı ve genel sekterinin imzaladığı ve cemiyet mührünü taşıyan bir kayıt belgesi (kimlik) verilmektedir. Üye olanlar kayıt sırasında bir sefere mahsus yarım lira ve aylık olarak 10 kuruş vermek zorundadır. Muhabir üyelerden üyelik ücreti alınmayıp, kimlikleri ücretsiz gönderilirken, fahri üyeler arzu etmeleri halinde 1 lira yardımda bulunarak kimlik alabilmektedir.

Bir yıllık üye aidatını ödemeyen üyeler seçim hakkını kaybetmekte, iki yıl aidat ödemeyenler cemiyet üyeliğinden çıkarılmaktadır.

Cemiyet, her ayın on beşinde, eczacılık bilimine ait konularda yazılan makalelerin yer aldığı, Türkçe ve Fransızca dillerinde aylık bir gazete yayınlanacak olup üyelere ücretsiz dağıtılacaktır. 
Cemiyetin şerefine aykırı hareket eden üyelerin genel kurulda 10 üyenin oyuyla cemiyetten çıkarılması teklif edilebilir ve 30 üyenin oy çokluğunda cemiyetten çıkarılabilir.

Cemiyetin Genel Kurulu, her yıl 20 Ağustos tarihinde yapılır. Genel kurulun yapılacağ1, bu tarihten on beş gün önce ilan edilir. Genel kurul gündemi cemiyet gazetesinde neşredilir. Genel kurulun dili Türkçe olup gerekmesi halinde yabancı dille de konuşma yapılabilir.

Eczacılık bilimine faydalı bir telif eseri cemiyet adına vücuda getirene cemiyet tarafından bir teşekkürname verilecek, eser sahibinin bir fotoğrafı da cemiyet salonuna asılacaktır.

Cemiyetin resmi mührü "Osmanlı Eczacı İttihad Cemiyeti" yazısının Türkçe ve Fransızcasıyla, cemiyetin kuruluş tarihi olan 1324 tarihini içerecek şekilde yapılacaktır. ${ }^{13}$

Yeni idare heyeti her y1l Genel Kurul'da belirlenecektir. Sadece kurucu idare heyetinin görev süresi özel olarak iki yıl olarak belirlenmiştir. Nizamnamenin yenilenme süresi 3 yıldır.

Cemiyet nizamnamesinin 18. maddesine göre "Cemiyet fünun-1 ispençiyariye ve makalât-ı müfide ve fenniyeden bahis şimdilik her ayın on beşinde Osmanlı ve Fransız lisanı üzere bir gazete neşr ve âzâ-yı daimeye işbu gazete meccanen tevzi ve irsal edilecektir." Cemiyet gazetesinin Türkçe ve Fransızca olarak çıkarılacağı belirtilmiş olmakla birlikte, cemiyet gazetesine bugüne kadar yapılan araştırmalarda tesadüf edilememiştir.

Cemiyet kurulmadan önce, 8 Ağustos 1908 tarihinde İstikamet Eczahanesi sahibi Eczac1 Hasan Rauf [Görgülü] Bey, Dâhiliye Nezareti'ne eczacılardan ve eczacılıktaki gelişmelerden söz edecek ve eczacılığa yönelik ilanları içerecek haftada veya on beş günde bir yayımlanacak İspençiyar isimli bir gazete çıkarmak için ruhsat başvurusunda bulunmuştur. ${ }^{14}$ Gazetenin yayın hayatına başladı̆̆ını Revue du Monde Musulman isimli derginin Mayıs 1909 sayısında yayınlanan listede görmekteyiz. ${ }^{15}$ Yine Hasan Rauf Bey tarafından çıkarılan ve ismi Union Pharmacetique Ottomane olan ve Fransızca olarak Temmuz 1908 ile Mayıs 1909 arasinda yayınlanan bir gazete daha bulunmaktadır. ${ }^{16}$ Revue du Monde Musulman isimli dergide, Fransızca yayınlanan bu gazetenin Ispençiyar isimli Türkçe gazetenin sahibi Eczacı Hasan Rauf Efendi tarafından günlük olarak yayınladığı ifade edilmektedir. ${ }^{17}$ Bu bilgiden hareketle cemiyetin ismiyle aynı ismi taşıyan bu gazetenin cemiyet bülteni mantığında hazırlanan bir yayın olduğu düşünülmektedir. Hasan Rauf tarafından çıkarılan bu iki gazeteye de şimdiye kadar tesadüf edilememiştir.

13 Cemiyet nizamnamesinde mührün üzerinde kuruluş tarihinin olması gerektiği yazdığı halde cemiyet mührüne “1324” tarihi yazılmamıştır. Mühür tarihsizdir. Bkz. Şekil 3.

14 BOA., DH. MKT. 1277-42-1, 12 Zilhicce 1326 (5 Ocak 1909).

15 "La Presse Musulmane," Revue du Monde Musulman 8, 5 (1909): 98; Baytop, Türk Eczacilık Tarihi Araştırmaları, 24-25.

16 G. Groc ve İ. Çağlar, La Presse française de Turquie de 1795 à nos Jours - Histoire et Catalogue (Istanbul: Éditions Isis, 1985), 187.

17 “La Presse Musulmane,” Revue du Monde Musulman 8, 5 (1909): 101. 


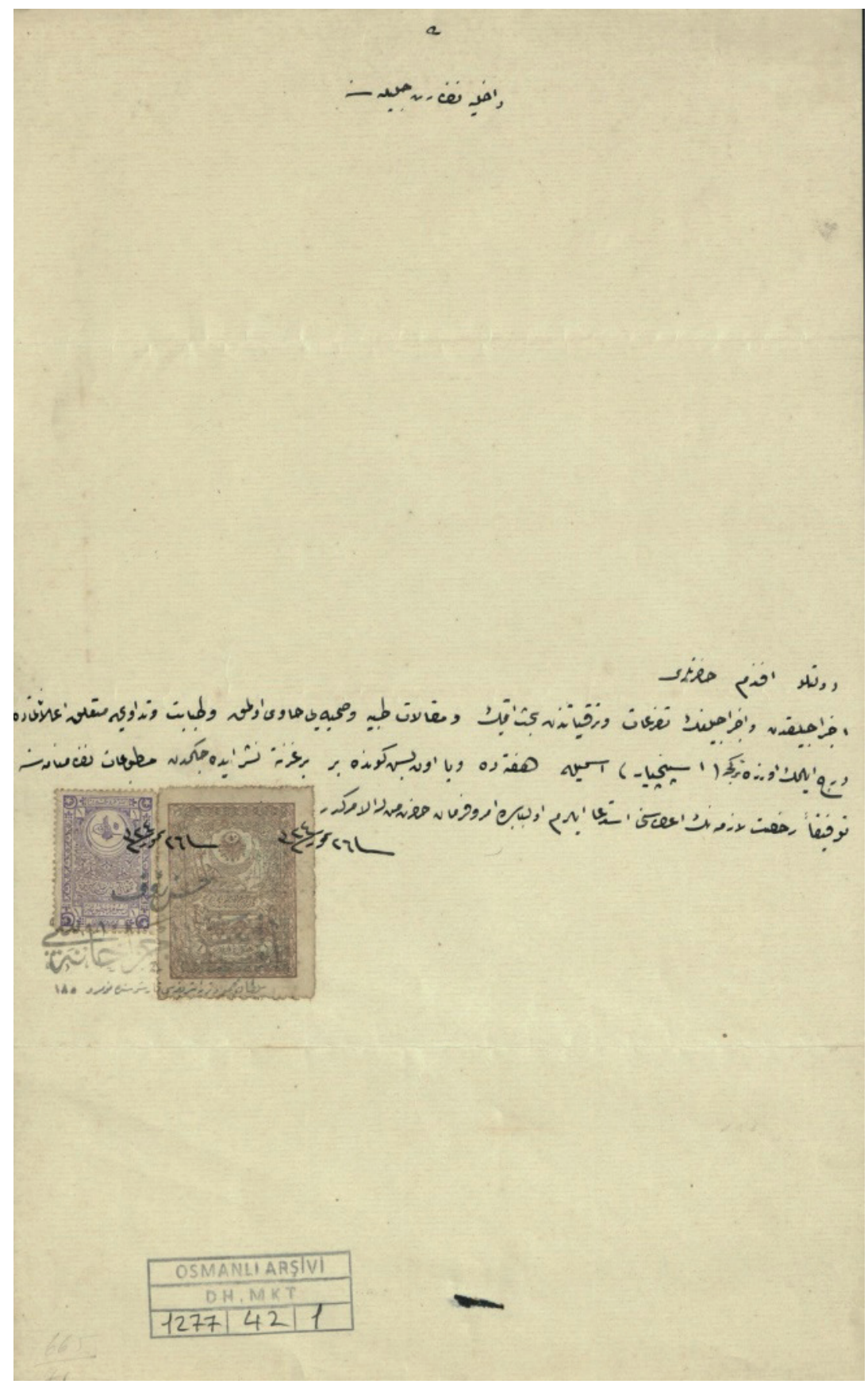

Şekil 4. Hasan Rauf [Görgülü] Bey tarafından çıkarılacak olan "İspençiyar" isimli gazete için yapılan ruhsat başvurusu. BOA., DH. MKT 1277-42-1, 12 Zilhicce 1326 (5 Ocak 1909) 


\section{Dâhiliye Nezareti Celilesine}

\section{Devletlü Efendim Hazretleri}

Eczacılıkdan ve eczacılığın tazarruat ve terakkiyatından bahs eden ve makalat-ı tibbiye ve sıhhiyeyi havi olmak ve tababet ve tedaviye müteallik ilanat da derc eylemek üzre Türkçe (İspençiyar) ismiyle, haftada veya on beş günde bir bir gazete neşr edeceğinden Matbuat Nizamnamesine tevfikan ruhsat-ı lazimenin itasını istida eylerim ol babda emrü ferman hazret-i men- lehü'l emrindir.

Fi 26 Temmuz 324 [8 Ağustos 1908]

(Kaşe)

Hasan Rauf

İstikamet Eczahanesi

Şekil 5. Hasan Rauf [Görgülü] Bey’in başvuru belgesinin transkripsiyonu

$\mathrm{Bu}$ iki gazetenin cemiyet yayını olup olmadıkları tartışmalıdır. Yayınlanmış olan bu iki gazetenin cemiyetin gazetesi olduğunu düşünmekle birlikte, Hasan Rauf [Görgülü] Bey'in Ispençiyar isimli gazetenin ruhsatı için başvurduğu tarih, 8 Ağustos 1908'dir. Osmanlı Eczacı İttihad Cemiyeti'nin kuruluş tarihinin 20 Ağustos 1908 olması ve cemiyetin kurucuları arasında Hasan Rauf Bey'in isminin bulunmamas ${ }^{18} \dot{I}_{\text {spençiyar gazetesinin }}$ doğrudan cemiyetin yayın organı olduğunu söylemek için yeterli değildir. Fakat gazetenin ruhsat almasının uzun sürebilme ihtimaline karşı cemiyetin kurulmasından önce ruhsat için başvurulmuş olabileceği cemiyet nizamnamesinde Türkçe ve Fransızca olarak bir derginin yayınlanmasının öngörülmesi ve gazetelerin birinin adının cemiyetin adıyla aynı olması bu iki gazeteyi de Osmanlı Eczacı İttihad Cemiyeti'nin gazetesi olarak yorumlamamızı sağlamaktadır. Bu konunun tam olarak aydınlığa kavuşabilmesi için ise bahse konu gazetelerden en az birer nüshanın bulunması gerekmektedir.

\section{Cemiyetin Kapanma Süreci ve Diğer Gelişmeler}

Cemiyet bünyesinde oluşturulan eczacı ve eczaneler kanunu komisyonu ile ilâç fiyat tarifesi komisyonu kendi konularında çalışmalar yapmıştır. Kanuna ve tarifeye yönelik

18 Farmakoloğ dergisinde bu cemiyetle ilgili bilgilerin olduğu makalede Hasan Rauf [Görgülü] Bey’in cemiyetin müteşebbislerinden ve idare heyeti üyesi olduğu zikredilmiştir. Bkz. Farmakoloğ, "Mesleğimizin Türkiye'deki Tarihçesi," Farmakoloğ 3, 7-8 (1933): 699. Baytop, Íspençiyar ve Union Pharmaceutique Ottomane isimli gazetelerin Osmanlı Eczacı İttihad Cemiyeti'nin Yönetim Kurulu üyesi Hasan Rauf [Görgülü] Bey tarafından çıkarıldığını söylemektedir. Bkz. Baytop, Türk Eczacılık Tarihi Araştırmaları, 24-25. Baytop'un verdiği bilginin kaynağının bu makale olması muhtemeldir. Hasan Rauf [Görgülü] Bey, cemiyetin resmi kurucuları arasında olmadığı halde daha sonradan seçilmiş olan bir yönetim kurulunda görev yapmış olabileceği düşünülürse bahse konu gazeteleri cemiyet yayın organı olarak nitelemek mümkün olacaktır. 
hazırlanan raporlar resmi makamlara gönderilmiştir. Bir süre sonra, yapılan bu çalışmalardan sonuç alınmamasından dolayı gayrimüslim eczacılar bu durumu bahane ederek cemiyetin iyi idare edilmediği iddiasında bulunmuşlardır. Bu surette cemiyetten ayrılmış ve yeni bir cemiyet kurmak üzere bir araya gelmişlerdir. ${ }^{19}$

Cemiyet'ten ayrılan gayrimüslim eczacılar, başlattıkları bu tartışmanın sonucunda 19 Kasım 1909 tarihinde bir toplantı yaparak yeni cemiyetin nizamnamesini hazırlamışlardır. Société des Pharmaciens de l'Empire Ottoman (Devlet-i Osmaniye Eczac1ları Cemiyeti) isimli bu cemiyetin nizamnamesi ile 2 Kânun-1 sani 1325 (15 Ocak 1910) tarihinde kuruluş ruhsatı alınmış ve cemiyet resmen kurulmuştur. Cemiyetin ilk başkanlığına Pierre Apéry seçilmiş ve resmi yazışma dili Fransızca olarak belirlenmiştir. ${ }^{20}$ Kurulan bu cemiyetin 9 kişilik idare heyeti üyelerinden sadece biri Türk’tür: Eczacı Lütfi Kamil Bey, idare heyetinde üye sıfatına sahiptir. ${ }^{21}$
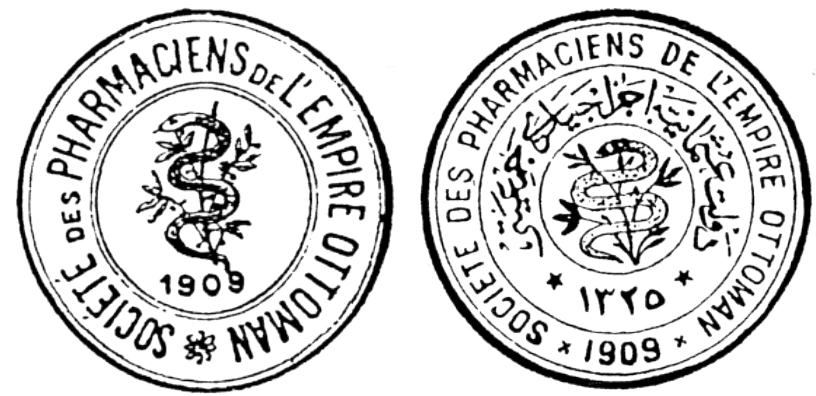

Şekil 6. Société des Pharmaciens de l'Empire Ottoman (Devlet-i Osmaniye Eczac1ları Cemiyeti) tarafından kullanılan iki farklı mühür. Baytop, Türk Eczacılık Tarihi Araştırmaları, 137.

Gayrimüslim eczacıların üyelikten ayrılmalarıyla Osmanlı Eczacı İttihad Cemiyeti'nin, gücü zayıflamıştır. Cemiyette kalan çok az sayıdaki Türk eczacı cemiyeti uzun süre devam ettirememiştir. Bazı arşiv belgeleri, Osmanlı Eczacı İttihad Cemiyeti'nin, Société des Pharmaciens de l'Empire Ottoman (Devlet-i Osmaniye Eczaciları Cemiyeti) kurulduktan sonra da faaliyetini sürdürmeye çalıştığına işaret etmektedir. ${ }^{22} 27$ Ağustos 1910'da Meclis-i Tıbbiye-i Mülkiye ve Sihhiye Umumiye'den, Dâhiliye Nezâreti'ne gönderilen yazıda hem Devlet-i Osmaniye Eczacıları Cemiyeti'nin hem de Osmanlı Eczacı İttihad Cemiyeti'nin verdiği beyannameler konu edilmiştir. Bu yazışma bize Osmanlı Eczacı İttihad Cemiyeti’nin 1910 yılının sonlarında da faaliyette olduğunu göstermektedir.

Osmanlı Eczacı İttihad Cemiyeti’nin kurucu başkanı olan Hamdi Bey 1909’da vefat

19 Farmakoloğ, "Mesleğimizin Türkiye'deki Tarihçesi," Farmakoloğ 3, 7-8 (1933): 699.

20 Baytop, "Osmanlı İmparatorluğu Döneminde Eczacılık Cemiyetleri," 149-151. Turhan Baytop, Eczâhâne'den Eczane’ye Türkiye'de Eczaneler ve Eczacılar (1800-1923) (İstanbul: Bayer, 1995), 30-31.

21 Naşit Baylav, Eczacılık Tarihi, 289.

22 BOA, DH. İrade (İD.) 126-1-1; 126-1-2; 126-1-3; 126-1-4, H, 10 Ramazan 1328 (15 Eylül 1910). 
etmiştir. Cemiyetin 1909 yılında bölünüp, gayrimüslim eczacıların ayrılmasında Hamdi Bey'in vefatının da bir etkisi olabilir. Şimdiki bilgilerimiz bunu tam olarak açıklamaya yetmemektedir.

\section{Cemiyet Kurucuları ve Komisyonlarında Görev Alan Eczacılar}

Çalışmamızın bu bölümünde, Osmanlı Eczacı İttihad Cemiyeti’nde kurucu olarak görev yapan ve cemiyetin eczacılar ve eczaneler kanunu komisyonu ile ilâç fiyat tarifesi komisyonunda görev yapan eczacıların kısa biyografilerine yer verilmiştir. ${ }^{23}$

\section{El-Hac Hamdi Bey}

Hamdi Bey 1879'da Mekteb-i Tıbbiye-yi Mülkiye'nin Eczacı Sınıfı'ndan mezun olmuş ve 1880'da Zeyrek Yokuşu'nda Eczahane-i Hamdi isimli eczanesini açmıştır. Eczane açan ilk Türk-Müslüman olarak kayıtlara geçen Hamdi Bey, bir süre Haseki Hastanesi'nin baş eczacılığını yapmıştır. 1895'te Zeyrek'teki eczanesini Vezneciler'deki Kuyucu Murad Paşa Medresesi'nin karşısına ve 1908'de Eminönü'ne taşımıştır. Eczanesinde, Müslüman eczacıların yetişmesi için büyük çaba sarf etmiştir. 1895 yılı mezunları Beşir Kemal [Pelin] Bey ve Mehmed Kâzım Bey ile 1897 yılı mezunu Cemal Kâzım Bey bu eczanede yetişip eczane açan en meşhur eczacılardandır.

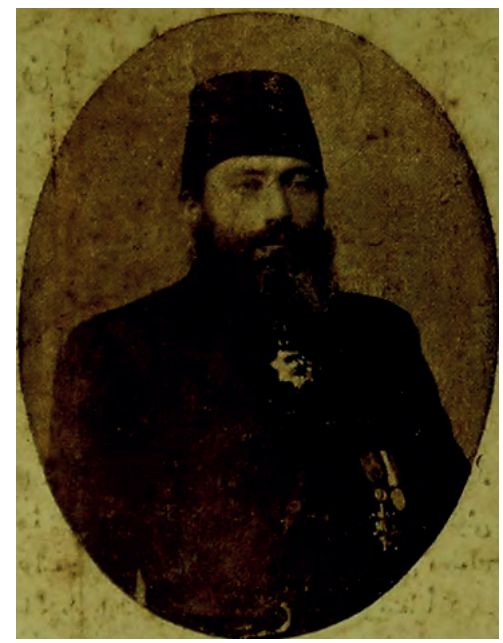

Şekil 7. Eczacı Hamdi Bey (ö. 1909) (Resimli Eczacı 13, 31 (Ağustos 1339 / Ağustos 1923), kapak sayfasi.

Hamdi Bey, eczacılığın bilimsel yönüyle de ilgilenmiş ve ilâç yapım yöntemleri üzerine dergilerde yazılar yazmıştır. ${ }^{4}$ Bilimsel çalışmaları nedeniyle kendisine Mecidî ve Osmanî

23 Biyografisi verilen eczacıların isimleri, cemiyetin yönetim kuruluna seçilirken aldıkları oyların en yüksek olandan en düşük olanına göre sıralanmıştır.

24 El Hadj Hamdi, "Procédé nouveau pour la préparation des extraits fluides par lixiviation," Revue MédicoPharmaceutique 23, 1 (1910): 4; Baytop, Eczahane'den Eczaneye, 82. 
nişanları verilmiştir. Darülaceze'ye verilecek ilaçları bedelsiz olarak sağladığı için Fahrî Eczacıbaşılık unvanı verilen Hamdi Bey'e ayrıca, eczanesinin kapısının üstüne de 'Armayı Hümayûn'u asma izni verilmiştir. 1909 yılında vefat eden Hamdi Bey ilaç üretimine de önem vermiştir. Eczanesinde ürettiği müstahzarların isimleri şunlardır: Kola Hamdi, Elixir Digestive Hamdi, Kefir, Liqueur de Goudron, Dermophile, Sirop iodotannique Phosphate, Gazo Aseto Tartare d'Aluminium. Vefatından sonra, Mekteb-i Tibbiye-yi Mülkiye'nin Eczacı Sınıfı 1902 mezunlarından olan oğlu Mustafa Asım Hamdi Bey eczaneyi işletmeye devam etmiştir. Hamdi Bey, Osmanlı Eczacı İttihad Cemiyeti’nin kurucu başkanlığını yapmıştır. ${ }^{25}$

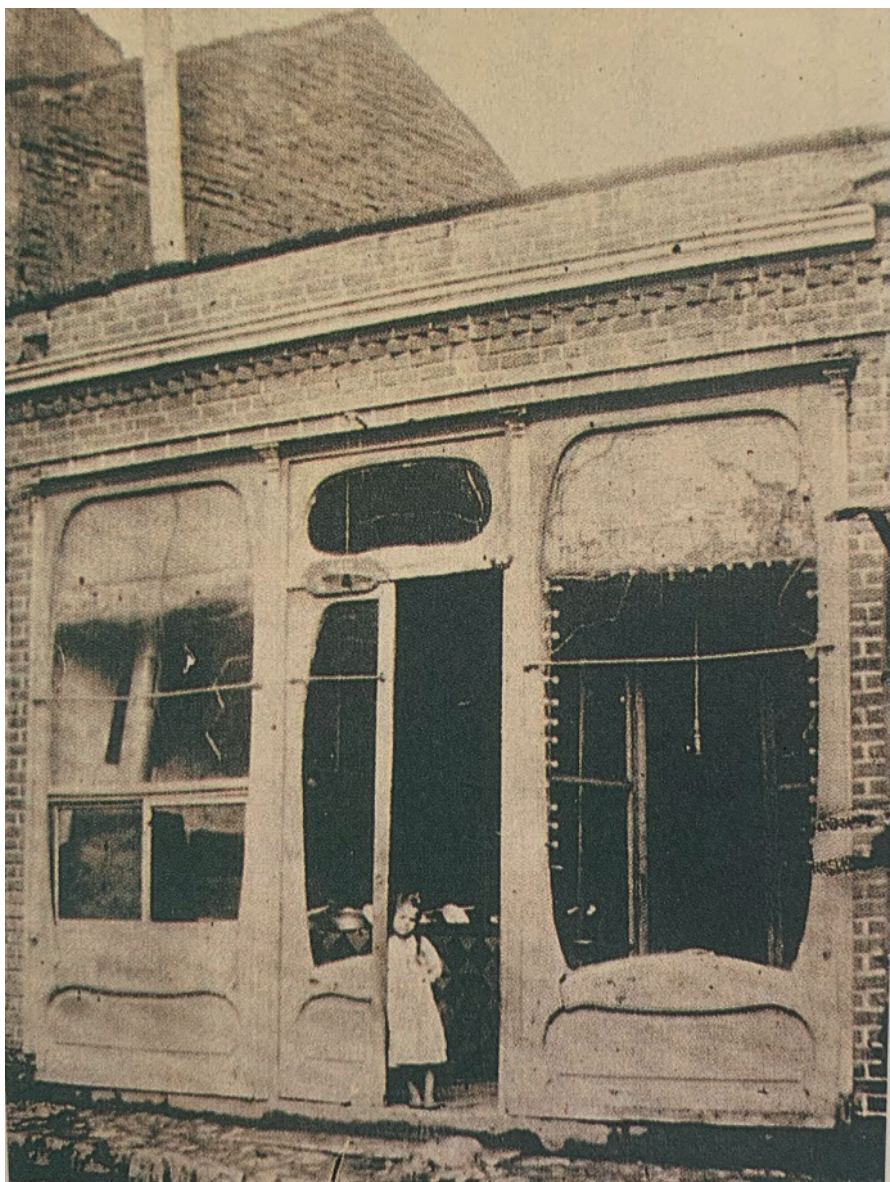

Şekil 8. Hamdi Bey’in Zeyrek’teki eczanesinin dış görünüşü. Baytop, Eczâhâne'den Eczane'ye, 82.

25 Farmakoloğ, "Hamdi Bey,” Farmakoloğ 3, 7-8 (1933): 707-708.; Baytop, Eczâhâne'den Eczane’ye, 82-84; Mert Sandalcı, Belgelerle Türk Eczacılığı V (İstanbul: Dr. Nejat Eczacıbaşı Vakfı, 2006), 114; Kocacık, Farmakoloğ, 43. 

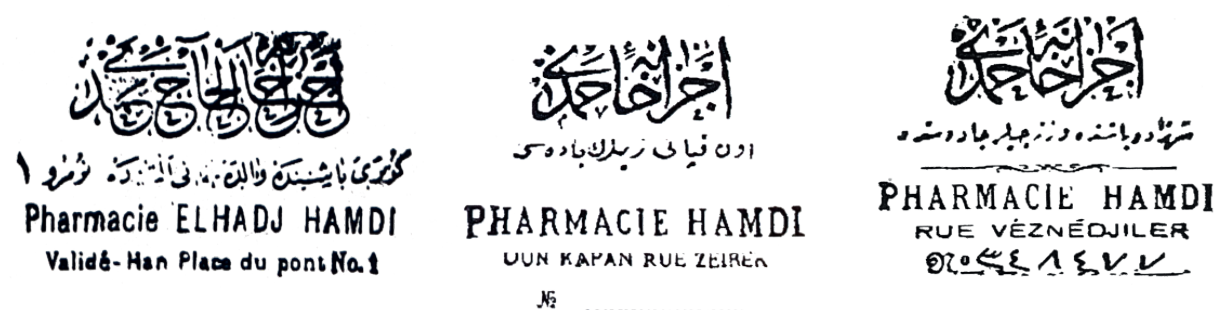

Şekil 9. Hamdi Bey’in eczanelerinde kullandığı mühürler. Baytop, Eczahane'den Eczane'ye, 84.

\section{Andrea Myrides}

Eczacı Andrea Myrides 1914-1921 yıllarında İstanbul'da Uzunçarşı Caddesi No: 307309 adresinde eczacılık yapmaktadır. ${ }^{26}$ Myrides, Osmanlı Eczacı İttihad Cemiyeti'nin kurucularından olup ilk idare heyetinin 2. başkanlığını yapmıştır. Hakkında başka bilgiye ulaşılamamıştır.

\section{Othont Cilaciyan}

1887'de eczacı diplomasını almış ve Kanzuk Eczahanesi'nde çalışmaya başlamıştır. Birinci Dünya Savaşı sırasında Arnavutköy'de eczane açmıştır. Uzun yıllar Ortaköy’de açtığı Othont Eczahanesi'ni işletmiştir. Eczane, Cumhuriyet döneminde Ortaköy Eczanesi ismini almıştır. Othont Cilaciyan, 1910 yılında Meclis-i Umur-1 Tıbbiye-i Mülkiye ve Sihhiye-i Umumiye'de eczacı delegesi olarak görev yapmıştır. 1929'da Carbonate de lithine effer Othont ve Benzoat de lithine effer Othont isimli iki ilaç için ruhsat alan Othont Cilaciyan 1942'de vefat etmiştir. Vefatından sonra eczaneyi 1945 mezunlarından Eczacı Münevver Akel Hanım işletmiştir. Eczane daha sonra Eczacı Sıtkı Seydim’e devredilmiştir. ${ }^{27}$ Cilaciyan, Osmanlı Eczacı İttihad Cemiyeti'nin kurucuları arasında olup ilk idare heyetinin üyeleri arasında görev yapmıştır.

\section{Edhem Pertev Bey}

Edhem Pertev Bey 1871'de Tırnova'da (Bulgaristan) doğmuş, 1895 'te Mekteb-i Tıbbiye-i Mülkiye'nin Eczacı Sınıfı'ndan mezun olmuş ve aynı yıl İstanbul, Aksaray'da Ethem Pertev Eczahanesi'ni açmıştır. İlk müstahzarı olan Pertev Şurubu'nu eczanesinde üretmiş daha sonra 1924'te Pertev Müstahzarat Laboratuvarı'nı kurmuş ve ilâç üretimine ağırlık vermiştir.

26 Alfred Rizzo, Annuaire Oriental (Constatinople: Imprimerie de l'Annuaire Oriental, 1921), 820; Sandalc1, Belgelerle Türk Eczacılı̆̆ $\mathrm{V}, 215$.

27 Mert Sandalcı, Belgelerle Türk Eczacıllğı I (İstanbul: Dr. Nejat Eczacıbaşı Vakfı, 1997), 53; Mert Sandalcı, Belgelerle Türk Eczacıllğ̆ II (İstanbul: Dr. Nejat Eczacıbaşı Vakfı, 1998), 89; Mert Sandalc1, Belgelerle Türk Eczacıllğgl II-2 (İstanbul: Dr. Nejat Eczacıbaşı Vakfı, 2003), 47; Mert Sandalcı, Belgelerle Türk Eczacıllğgl IV (İstanbul: Dr. Nejat Eczacıbaşı Vakfi, 2000), 64. 
Yaptığı ilâçlarla yurtiçinde ve yurtdışında birçok sergiye katılan Edhem Pertev Bey birçok şeref madalyası kazanmıştır. 1924'te Türkiye Eczacıları Cemiyeti'nin başkanlığına seçilen Edhem Pertev Bey mesleki konular üzerine çok fazla mesai harcamıştır. Meslek tarihi içerisinde çok özel bir yere sahip olan Edhem Pertev Bey, döneminin eczacilar tarafindan büyük sayg1 görmüştür. Vefatından sonra uzun bir süre her ölüm yıl dönümünde Türkiye Eczacıları Cemiyeti tarafından anma törenleri düzenlenmiştir. Ürettiği müstahzarların isimleri şöyledir: Pertev Şurubu, Pertev Dower Komprimeleri, Kınakınalı Pertev Saç Suyu, Kinin Klorhidrat Pertev, Pertev Diş Macunu, Pertev Diş Tozu, Pertev DişS Suyu, Pertev Çocuk Pudrasl. $^{28}$
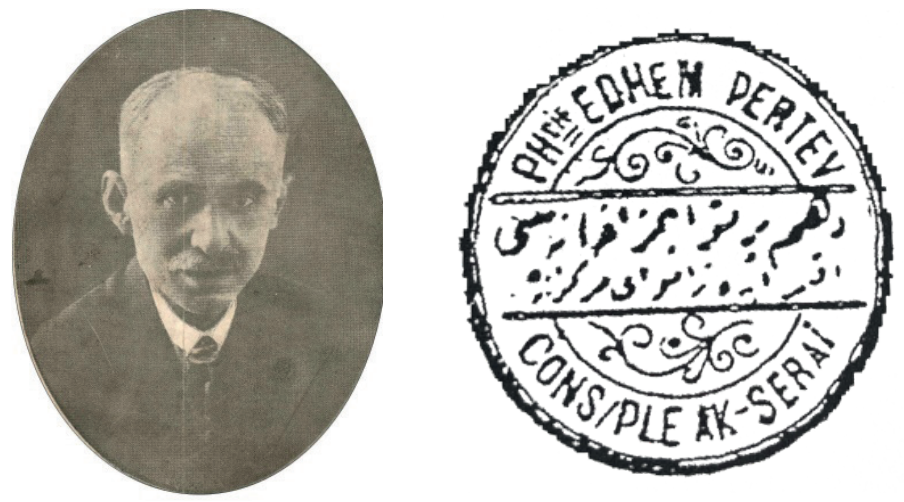

Şekil 10 (solda). Edhem Pertev Bey (1887-1927) (Eyüp Talha Kocacık Arşivi)

Şekil 11 (sağda). Edhem Pertev Bey’in eczanesinde kullandığı mühür (Eyüp Talha Kocacık Arşivi)

12 Haziran 1927'de vefat eden Edhem Pertev Bey'in eczanesi ve ilâç laboratuvarı, ortağ1 Eczacı Niyazi Özmay tarafından devam ettirilmiştir. Edhem Pertev Eczanesi'ni Eczacı Mektebi'nden 1935'te diploma almış olan Mefharet Ertem Hanım 1945 yılına kadar işletmiştir. Edhem Pertev Bey'in oğlu Pertev Ertem 1945'te Eczacı Okulu'ndan diploma aldıktan sonra eczaneyi 1960 yılına kadar işletmiştir. Pertev Ertem sağlık sorunları sebebiyle 1960'da eczaneyi 1958 yılı mezunlarından Eczacı Eli Ventura'ya devretmiş ve eczanenin adı Emel Eczanesi olarak değiştirilmiştir. ${ }^{29} \mathrm{Bu}$ eczane 1985 'te kapanmıştır. Edhem Pertev Bey'in eczanesine ait birçok kavanoz ve şişe Pertev Ertem tarafından Türk Eczacılık Tarihi Müzesi'ne devredilmiştir. ${ }^{30}$ Edhem Pertev Bey, Osmanlı Eczacı İttihad Cemiyeti’nin kurucusu olup ilk idare heyetinin üyeleri arasında görev yapmıştır.

28 Sandalc1, Belgelerle II, 113-115; Mert Sandalc1, Belgelerle Türk Eczacıllğı III (İstanbul: Dr. Nejat Eczacıbaş1 Vakfi, 1999), 77-79; Mert Sandalc1, Belgelerle Türk Eczacılığı III-2 (İstanbul: Dr. Nejat Eczacıbaşı Vakfi, 2005), 92-95; Sandalc1, Belgelerle IV, 120-145; Sandalc1, Belgelerle V, 248.

29 Baytop, Eczahane'den Eczane'ye, 74-79.; Eyüp Talha Kocacık, “Edhem Pertev Bey Günü,” Eczacı 16, 181 (2020): 28-29.; Kocacık, Farmakoloğ, 43.

30 İstanbul Üniversitesi Eczacılık Fakültesi’nin içerisindeki bu müze, Türk Eczacılık Tarihi İhtisas Müzesi adıyla Kültür Bakanlığı tarafından onaylanmıştır. Müzeye ziyaret özel izinle yapılabilmektedir. 


\section{Mehmed Kâzım Bey}

Osmanlı Eczacı İttihad Cemiyeti’nin kurucularından olup ilk idare heyetinin üyeleri arasında görev alan Mehmed Kâzım Bey’in soyadı bilinmediğinden hangi Mehmed Kâzım olduğu tespit edilememiştir. 1895'te Mekteb-i Tıbbiye-i Mülkiye'nin Eczacı Sınıfı'ndan mezun olup Beşiktaş’ta eczacılık yapan Mehmed Kâzım olabileceği gibi, 1899'da mezun olup Fatih'te eczacılık yapan başka bir Mehmed Kâzım da olabilir. ${ }^{31}$ İleride bulunacak başka bilgilerle bu konu açıklığa kavuşturulabilir.

\section{Jacques Ezekiel Garih (Jak Garih)}

1896'da Mekteb-i Tıbbiye-i Mülkiye'nin Eczacı Sınıfı'ndan eczacı diplomasını almış ve Ortaköy'de eczane açmıştır. 1921'de Garih Eczanesi'ni Beyoğlu Postacılar Sokak No: 5'e taşımıştır. 1934'de eczaneyi İstiklal Caddesi No: 419'a taşımış ve 1939'da Eczacı Necati Gözübüyük'e devretmiştir. Eczaneyi devralan Necati Bey, ismini İstiklal Eczanesi olarak değiştirmiştir. ${ }^{32} \mathrm{Bu}$ eczane aynı adla İstiklal Caddesi’nde Necati Bey’in oğlu Eczacı Faruk Gözübüyük tarafından 2020 yılına kadar işletilmiştir. Garih, Osmanlı Eczacı İttihad Cemiyeti'nin kurucuları arasında olup ilk idare heyetinde üye sıfatıyla görev yaparken aynı zamanda eczacılar ve eczaneler kanunu komisyonu ile ilâç fiyat tarifesi komisyonunda da görev yapmıştır.

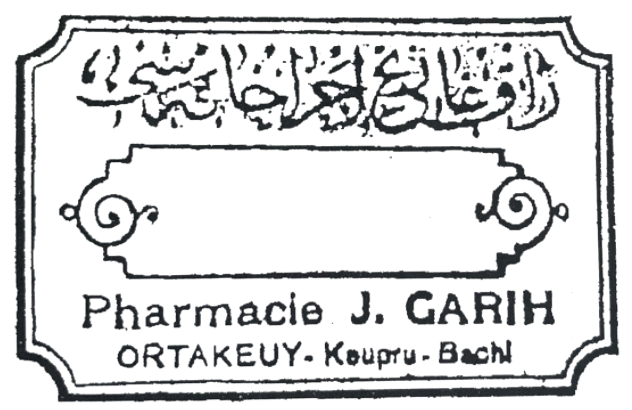

Şekil 12. Jacqeues Garih'in eczanesinde kullandığı mührü. Baytop, Eczahane'den Eczane 'ye, 105.

\section{Hakkı Bey}

Hakkı Bey'in kim olduğu tam olarak tespit edilememiştir. Osmanlı Eczacı İttihad Cemiyeti'nin kurucuları arasında olup ilk idare heyetinde üye sıfatıyla görev yapmıştır.

31 Baytop, Türk Eczacılık Tarihi, 146; Sandalcı, Belgelerle V, 167.

32 Remzi Kocaer, Türkiye Eczacılar Almană̆ı 1949 (İstanbul: Hüsnütabiat Basımevi, 1949), 327; Sandalc1, Belgelerle V, 114. 


\section{Agop Maksud Nargileciyan}

1904'te Mekteb-i Tibbiye-i Mülkiye'nin Eczacı Sınıfı'ndan eczacı diploması alan Nargileciyan, babası Maksud Garabet Nargileciyan tarafindan 1878'de Yenikapı'da açılan eczanede 1909 yılına kadar birlikte çalışmıştır. 1909'da Agop Maksud Bey eczaneyi Pangaltı'na taşımıştır. Fitinli Maksut Şurubu ve Terpestesin Ampulleri isimli iki müstahzar da üreten Nargileciyan, 1960 yılı başında eczaneyi 1944 yılı mezunu eczacı Niyazi Atakan'a devretmiştir. Atakan da eczaneyi 1988 yılına kadar işletmiş ve sonrasında kapatmıştır. ${ }^{33}$ Nargileciyan, Osmanlı Eczacı İttihad Cemiyeti'nin kurucuları arasında olup ilk idare heyetinde üye sıfatıyla görev yapmıştır.

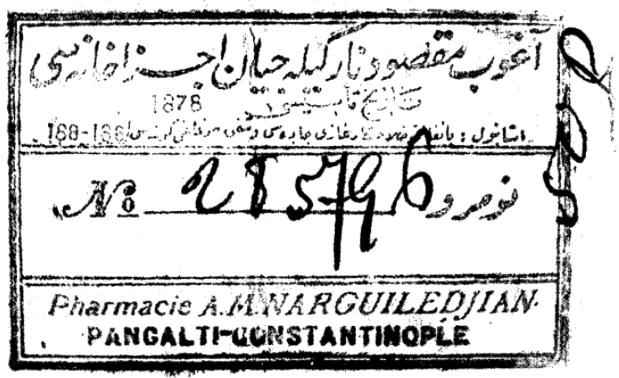

Şekil 13. Agop Maksud Nargileciyan'ın eczanesinde kullandığı mühür. Sandalcı, Belgelerle II, 193.

\section{Vasilyadis Efendi}

Vasilyadis Efendi'nin nizamnamede sadece soyadı yazılı olduğundan hakkında bilgi bulunmamaktadır. Zira bugüne kadar Vasilyadis soyadını kullanan on üç eczacı tespit edilmiştir. Bunların hangisinin cemiyetin kurucusu olan Vasilyadis Efendi olduğu belirsizdir. Vasilyadis Efendi, Osmanlı Eczacı İttihad Cemiyeti'nin kurucuları arasında olup ilk idare heyetinde üye sıfatıyla görev yapmıştır.

\section{Beşir Kemal [Pelin] Bey}

1876'da Halep'de doğmuş ve 1897'de Mekteb-i Tibbiye-i Mülkiye'nin Eczacı Sınıfı'ndan mezun olmuştur. 1898'de Eczacı Hamdi Bey ile ortak olarak Bahçekapı'da Halep Eczahanesi'ni açmıştır. Daha sonra eczanenin adını Beşir Kemal Eczahanesi olarak değiştirmiş ve 1917'de Sirkeci'ye taşımıştır. 1922 yılı mezunu Mahmut Cevat [Pelin] Bey’i manevi oğlu olarak kabul eden Beşir Kemal Bey, 1929'da onu eczaneye ortak olarak almış ve aynı yıl 'Beşir Kemal Mahmud Cevad ve Şeriki Eczane ve Müstahzaratı Komandit Şirketi'ni kurmuştur. Türkiye Eczacıları Cemiyeti’nin de kuruculuğunu yapmıştır. İlâç üretimine çok

33 Sandalc1, Belgelerle II, 193-195; Sandalc1, Belgelerle V, 218. 
önem veren Beşir Kemal Bey şu müstahzarları üretmiştir: Beşir Kemal Balık Yağı Sübyesi, Beşir Kemal Kınakına Hülasası, Beşir Kemal Nasır Ilacı, Beşir Kemal Sıhhat Enfiyesi. Beşir Kemal Bey'in 12 Mart 1942'de vefat etmesi üzerine eczaneyi Mahmut Cevat Bey idare etmiştir. 1954'te Mahmut Cevat Bey'in de vefat etmesi üzerine eczane 1938 mezunu Halit Öncel'e devredilmiştir. Eczane, 1984'de Bakırköy'e taşınmıştır. ${ }^{34}$ Beşir Kemal Bey, Osmanlı Eczacı İttihad Cemiyeti'nin kurucuları arasında olup ilk idare heyetinde üye sıfatıyla görev yapmıştır.
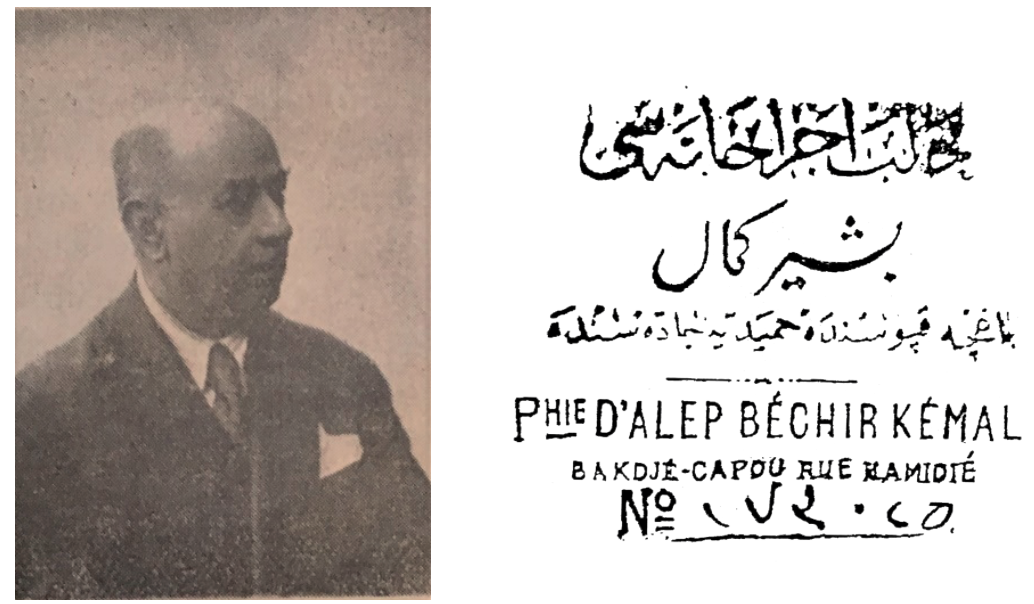

Şekil 14 (solda). Beşir Kemal Bey (1876-1942). Eyüp Talha Kocacık Arşivi

Şekil 15 (sağda). Beşir Kemal Bey’in eczanesinde kullandığı mühür. Eyüp Talha Kocacık Arşivi

\section{J. M. Kalikiyopulos}

J. M. Kalikiyopulos, 1868 'de Galata'da Karaköy Caddesi'nde Madella Eczahanesi ismiyle faaliyet gösteren eczaneyi devir almış ve aynı isimle işletmeye devam etmiştir. Eczane 1920 yılına doğru kapanmıştır. ${ }^{35}$ Kalikiyopulos, Osmanlı Eczacı İttihad Cemiyeti’nin kurucuları arasında olup ilk idare heyetinde üye sıfatıyla görev yapmıştır.

\section{Sava Vasil Nazlıoğlu}

1888 y1lı itibariyle Aksaray'da Vatan Eczahanesi'nin sahibi olarak gözükmektedir. 1910’da eczanesi açıktır. ${ }^{36}$ Nazlıŏlu, Osmanlı Eczacı İttihad Cemiyeti’nin kurucuları arasında olup ilk idare heyetinde üye sıfatıyla görev yapmıştır.

34 “Ölenlerimiz," Farmakoloğ 12, 1-4 (1942): 46-48; Baytop, Eczahane'den Eczane'ye, 80-81; Sandalc1, Belgelerle I, 157-211; Sandalc1, Belgelerle III-2, 204-206; Sandalc1, Belgelerle IV-2, 138-148; Kocac1k, Farmakoloğ, 90, 208.

35 Sandalc1, Belgelerle II, 29-30; Sandalc1, Belgelerle II-2, 100.

36 Sandalc1, Belgelerle $V, 219$. 


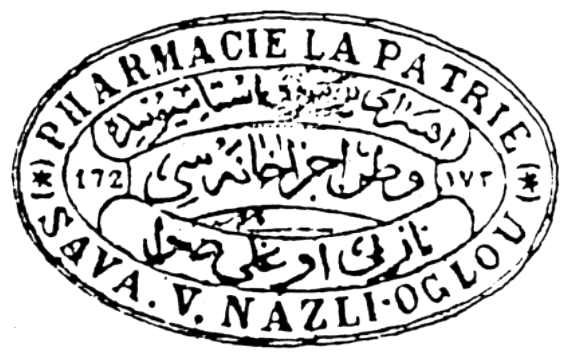

Şekil 16. Sava Vasil Nazlığlu'nun eczanesinde kullanıldığı mühür. Baytop, Eczahane'den Eczane'ye, 66

\section{Pierre Apéry}

1852'de doğan Pierre Apéry, 1872'de Mekteb-i Tıbbiye-i Mülkiye'nin Eczacı Sınıfı'ndan mezun olmuştur. 1874'te Galata'da 1850'li yıllarda açılan Vélits Eczanesi'ni devralarak Büyük Eczahane ismiyle yeniden açmıştır. 1908' de bu eczaneyi başka bir binaya taşımış ve eczanenin adını Pierre Apéry Eczahanesi olarak değiştirmiştir. Eczacılık alanında çok farklı bir konumu olan Apéry, bir tahlil laboratuvarı da kurmuştur. Revue Médico-Pharmaceutique dergisinin uzun süre başyazarlığı yapmıştır. Annuaire Oriental de Médecine et de Pharmacie isimli kitabın yazarıdır. Gazette Médicale d'Orient, Journal de la Société de Pharmacie de Constantinople isimli dergilerde bilimsel yazılar yazmıştır. Société de Pharmacie de Constantinople (Cemiyet-i Eczaciyan der Asitâne-i Aliyye) ve Société des Pharamciens de l'Empire Ottoman (Devlet-i Osmaniye Eczacıları Cemiyeti) isimli eczac1lık cemiyetlerinin kurucu üyeliğini ve başkanlıklarını yapmıştır. 24 Ocak 1918'de vefat etmiştir. ${ }^{37}$ Osmanlı Eczacı İttihad Cemiyeti'nin eczacılar ve eczaneler kanunu komisyonunda görev yapmıştır.

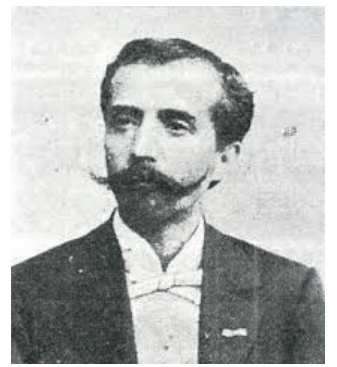

\section{Pharmacle P. A.PÉRY GALA IA. KUE VeIVoG \\ - CUIE de la POSTE FR'ANY̧AISE ol un Irịid des Ponilis Aliemanile \& Russe}

Şekil 17 (solda). Pierre Apéry (1852-1918). Eyüp Talha Kocacık Arşivi

Şekil 18 (sağda). Pierre Apéry'nin eczanesinde kullandığı mühür. Eyüp Talha Kocacık Arşivi

37 Baytop, Eczâhâne'den Eczane'ye, 96-97; Sandalc1, Belgelerle III, 24-26; Michèle Nicolas, "Pierre Apéry et ses Publications scientifiques," Revue d'Histoire de la Pharmacie 350 (2006): 237-247. 


\section{Léon Fridman Irinéu}

Viyana Üniversitesi Kimya Fakültesi'nden mezun olmuştur. 1895'te İstanbul'da kimya laboratuvarı açmıştır. Giorgo Dellasudda'nın (Faik Paşa) damadı olmuştur. Dellasudda'nın ölümü üzerine Büyük Della-Sudda Eczahanesi’ni işletmiş bir süre sonra eczaneyi kapatarak sadece kimya laboratuvarıyla ilgilenmiştir. ${ }^{38}$ Osmanlı Eczacı İttihad Cemiyeti’nin eczacılar ve eczaneler kanunu komisyonunda görev yapmıştır.

\section{Jean César Reboul}

1870'de doğmuş ve Paris Eczacılık Yüksek Okulu'ndan diploma almıştır. 1895'te Beyoğlu'nda Büyük Paris Eczahanesi'ni açmıştır. 1909'da kurulan Devlet-i Osmaniye Eczacıları Cemiyeti'nin (Société des Pharmaciens de l'Empire Ottoman) kuruculuğunu ve başkanlığını yapmıştır. Uzun süre Şark Merkez Ecza Deposu'nun yönetim kurulu üyeliğinde bulunmuştur. Eczanesinde ürettiği müstahzarlar: Vin Reboul, Pepto-Fer Reboul, Sirop Pectoral Reboul, Elixirs Digestifs Reboul. 1924 mezunu Kemal Müderrisoğlu bu eczanede çalışmaya başlamış, 1928'de Reboul ile ortak olmuş ve 1940'da eczaneyi tamamen satın almış olup bugün bu eczane oğlu Eczacı Mehmet Müderrisoğlu'nu tarafından işletilmektedir. Reboul, Osmanlı Eczacı İttihad Cemiyeti’nin eczacılar ve eczaneler kanunu komisyonunda görev yapmıştır. ${ }^{39}$

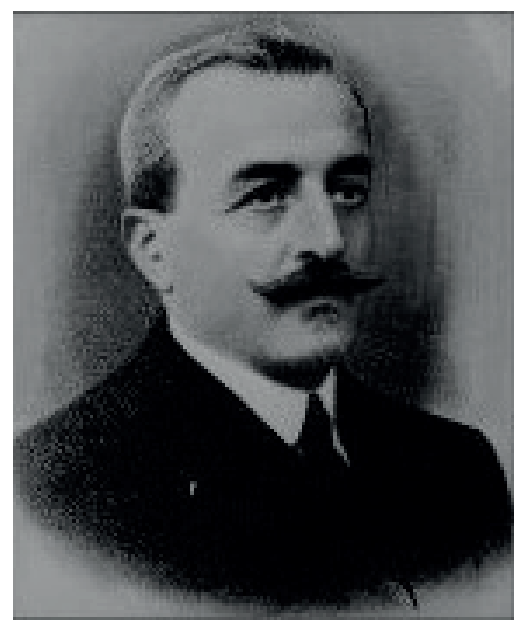

Şekil 19. Jean Cesar Reboul (1870-1944). Eyüp Talha Kocacık Arşivi

38 Sandalc1, Belgelerle V, 110

39 Baytop, Eczâhâne'den Eczane'ye, 100-104; Mert Sandalc1, Belgelerle Türk Eczacılığı I-2, (İstanbul: Dr. Nejat Eczacıbaşı Vakfı, 2002), 218-219; Sandalc1, Belgelerle III-2, 210-214; Mert Sandalc1, Belgelerle Türk Eczacılığı IV-2 (İstanbul: Dr. Nejat Eczacıbaşı Vakfi, 2001), 156-165. 


\section{Vincent Giannetti (Canzuch)}

Joseph Canzuch'un İngiliz Eczahanesi'nde 1900'de çalışmaya başlayan Vincent Giannetti, 1911'de eczanenin sahibi olmuştur. Birinci Dünya Savaşı sırasında eczanenin adını Kanzuk Eczahanesi olarak değiştirmiştir. Giannetti'nin 20 Nisan 1929'da vefat etmesi üzerine kardeşi Eczacı Sylvio Giannetti, eczaneyi işletmeye devam etmiştir. 1922'de eczacı diploması alan Muhiddin Hüsnü Bey, 1932'de eczaneyi satın alarak ismini İngiliz Kanzuk Eczanesi olarak değiştirmiş ve işletmeye başlamıştır. Kendi soyadını da Kanzuk olarak alan Muhhiddin Hüsnü Bey, eczaneyi 1965 yılına kadar işletmiş ve sonra kapatmıştır. ${ }^{40}$ Vincent Giannetti, Osmanlı Eczacı İttihad Cemiyeti'nin eczacılar ve eczaneler kanunu komisyonunda görev yapmıştır.

\section{Hasan Rauf [Görgülü] Bey}

1874'te doğan Hasan Rauf Bey, 1899'da Mekteb-i Tibbiye-i Mülkiye'nin Eczac1 Sınıfı'ndan mezun olmuştur. 1900'de Haçik Emirzeyan'a ait Numune Eczahanesi'ni satın almış ve adını İstikamet Eczahanesi olarak değiştirmiştir. Divanyolu'nda bulunan bu eczane yangınlar sebebiyle birkaç kez yer değiştirmek zorunda kalmıştır. Hasan Rauf Bey eczanesinde müstahzar yapımına önem vermiş ve ayrıca bir laboratuvar da kurmuştur. Eczacı Mektebi'nin öğrencilerinin bu eczaneye gelerek müstahzar hazırlamak için kullanılan aletlerle çalıştıklarını ve tecrübe edindiklerini bilmekteyiz. Yukarıda bahsettiğimiz Ispençiyari ve Union Pharmaceutique Ottomane isimli Türkçe ve Fransızca gazetelerin sahibi olan Hasan Rauf Bey, Osmanlı Eczacı İttihad Cemiyeti'nin eczacılar ve eczaneler kanunu komisyonunda ve cemiyetin gazetelerinin çıkarılmasında görev yapmıştır. ${ }^{41}$ Hasan Rauf Bey eczanesini Eczacı Mustafa Nahid Bey’e devretmiş, bir ithal ilâç firmasında mesul müdürlük yapmış ve 5 Ekim 1945 'te vefat etmiştir. Ürettiği müstahzarların isimleri şunlardır: Güyo katran, Pebeko Diş Macunu, Rauf Diş Tozu, Dermatin Rauf, Rauf Kolonyası, Kumral ve Siyah Türk Saç Boyası. 1922'de eczacı diplomasını alan Sırrı Rasim Aktulga, 1924'te Nahid Bey'den İstikamet Eczanesi devralmıştır. Eczane, 1979'da Sırrı Rasim Bey’in oğlu Eczacı Erol Aktulga'ya geçmiş ve Erol Bey'in vefatından bir yıl sonra 1986'da kapanmıştır. Eczaneye ait dolaplar ve bazı malzemeler 1986 yılında Türk Eczacılık Tarihi Müzesi için satın alınmış ve müzeye konulmuştur. ${ }^{42}$

40 Baytop, Eczâhâne'den Eczane'ye, 107; Sandalc1, Belgelerle I, 46-51; Sandalc1, Belgelerle I-2, 70-77; Sandalc1, Belgelerle II, 80-82; Sandalc1, Belgelerle III, 61-88.

41 Eczacılık tarihi ile ilgili daha önce yapılan yayınlarda Hasan Rauf [Görgülü] Bey'in Osmanlı Eczacı İttihad Cemiyeti'nin kurucusu ve yönetim kurulu üyesi olduğu zikredilmektedir. Gerek yaptığımız araştırmalarda gerekse de nizamnamesinde yazan kurucu idare heyeti üyelerinin arasında Hasan Rauf Bey'in adı geçmemektedir.

42 Baytop, Eczâhâne'den Eczane'ye, 86-87; Sandalc1, Belgelerle I-2, 122-123; Sandalc1, Belgelerle III-2, 116117. 


\section{Eugène Dellasuda}

Eugène Dellasuda, 1880'de Cadde-i Kebir'de Eczahane-i Öjen Dellasuda adiyla bir eczane açmıştır. 1921'de eczane aynı yerde işletilmeye devam etmektedir. Eugène Dellasuda, eczanesinde Sirop d'iodure de fer phosphate isimli bir müstahzar üretmiştir. Yine bu müstahzar üzerine bir kitap yazmıştır. ${ }^{43}$ Dellasuda, Osmanlı Eczacı İttihad Cemiyeti’nin eczacılar ve eczaneler kanunu komisyonunda görev yapmıştır.

\section{Jean Jurescu}

Jean Jurescu Galata Merkez Eczahanesi adıyla bir eczane açmıştır. Eczanenin açılış tarihi tam olarak bilinmemekle birlikte 1923 yılında açık olduğu tespit edilmiştir. ${ }^{44} 1902$ yılında Revue Medico-Pharmaceutique gazetesinde ilaç hazırlama tekniğiyle ilgili yapılan bir tartışmada Jurescu'nun adı geçmektedir. Bu durum Jurescu'nun uzun dönem eczacılık yaptığına işaret etmektedir. ${ }^{45}$ Jean Jurescu, Osmanlı Eczacı İttihad Cemiyeti'nin eczacılar ve eczaneler kanunu ve ilaç fiyat tarifesi komisyonlarında görev yapmıştır.

\section{Hüseyin Hüsnü Bey}

Hüseyin Hüsnü Bey’in kim olduğu tam olarak tespit edilememiştir. Osmanlı Eczacı İttihad Cemiyeti'nin eczacılar ve eczaneler kanunu komisyonunda görev yapmıştır.

\section{Elias Tchitchekian (Çiçekyan)}

Elias Çiçekyan 1878' de eczacı diplomasını almış ve beş yıl Yemen'de askeri eczacı olarak görev yaptıktan sonra 1884'te Kadıköy, Yel Değirmeni'nde eczane açmıştır. Eczanesini daha sonra Moda Caddesi'ne taşımış 1926 yılında vefat etmiştir. ${ }^{46}$ Çiçekyan, Osmanlı Eczacı İttihad Cemiyeti'nin eczacılar ve eczaneler kanunu komisyonunda görev yapmıştır.

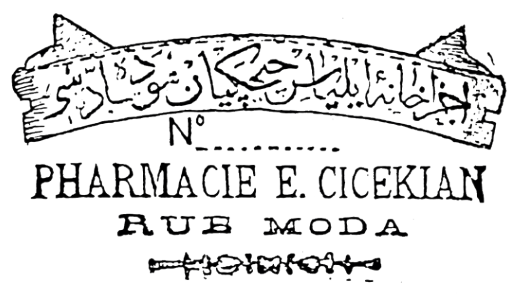

Şekil 20. Elias Çiçekyan'ın Moda Caddesi'nde bulunan eczanesinde kullandığı mühür.

Baytop, Eczâhâne'den Eczane'ye, 62.

43 Sandalcı, Belgelerle I, 63; Baytop, Eczahane'den Eczane'ye, 99. Eugène Dellasuda şeklinde yazılıdır.

44 Sandalc1, Belgelerle I, 116.

45 Revue Medico-Pharmaceutique 15, 4 (1902): 42; Revue Medico-Pharmaceutique 15, 8 (1902): 91-92; Baytop, Türk Eczacıllk Tarihi, 138.

46 Sandalc1, Belgelerle V, 72. 


\section{Ibrahim Halil Bey}

İbrahim Halil Bey’in kim olduğu tam olarak tespit edilememiştir. Osmanlı Eczacı İttihad Cemiyeti'nin ilaç fiyat tarifesi komisyonunda görev yapmıştır.

\section{Tsalikes Efendi (Tsalikes / Tsaliki ?)}

Tsalikes Efendi’nin kim olduğu tam olarak tespit edilememiştir. Osmanlı Eczacı İttihad Cemiyeti'nin ilaç fiyat tarifesi komisyonunda görev yapmıştır.

\section{Jean Mavrikides}

Jean Mavrikides, İstanbul Büyükdere'de Mavrikides Eczahanesi'ni açmıştır. Eczaneni tam olarak hangi yıl açıldığı bilinmemekle birlikte 1888-1914 yılları arasında açık olduğu tespit edilmiştir. ${ }^{47}$ Mavrikides, Osmanlı Eczacı İttihad Cemiyeti'nin ilaç fiyat tarifesi komisyonunda görev yapmıştır.

\section{Değerlendirme ve Sonuç}

Osmanlı Eczacı İttihad Cemiyeti’nin meslek cemiyetleri tarihi içerisinde Türk eczacıların öncülüğünde kurulan ilk cemiyet olduğu söylenebilir. Cemiyetin yazışma ve toplantı dilinin Türkçe olması, cemiyet adına Türkçe ve Fransızca dillerinde ve cemiyet gazetesi şeklinde bir yayının planlanmış olması, İkinci Meşrutiyet'in ilk yıllarında İttihad ve Terakki Cemiyeti'nin oluşturmaya çalıştığı Osmanlı millet kavramına örnek teşkil etmektedir. Cemiyetin isimdeki "İttihad" kelimesini bunu ifade etmektedir. Yaklaşık iki yıl boyunca faaliyet göstermiş olan cemiyet, resmi olarak kapatılmadan dağılmıştır. Gayrimüslim eczacıların cemiyetten kısa sürede ayrılmaları, bu eczacıların büyük kısmının Türk eczacıların yönetimindeki bir dernek çatısı altında toplanmak istemediklerinin göstergesidir. Hasan Rauf [Görgülü] Bey tarafından çıkarılan İspençiyar isimli gazetenin cemiyete ait olup olmadığı tam olarak tespit edilememekle birlikte Türkçe olarak yayınlanan ilk eczacılık gazetesi olduğu söylenebilir.

47 Sandalc1, Belgelerle $I V-2,81$. 


\section{EK: OSMANLI ECZACI ITTTIHAD CEMIYETI NIZAMNAMESI}

(BOA, DH. MKT. 2673-3-1, 9 Zilkade 1326 / 3 Aralık 1908)

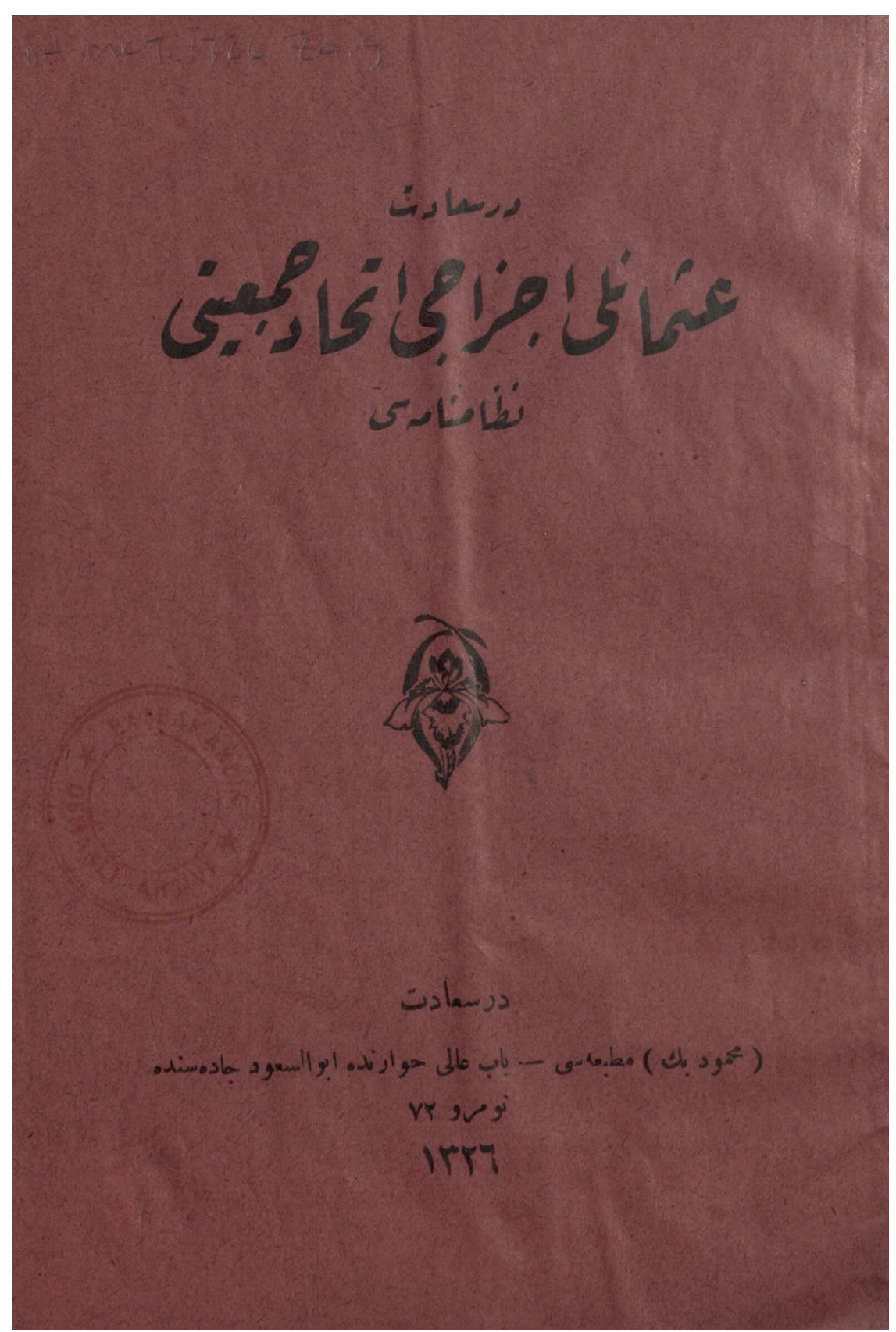




\section{Dersaadet \\ OSMANLI ECZACI İTTIHAD CEMIYYETI}

Nizamnâmesi

\section{Dersaadet}

(Mahmud Bey) Matbaası- Bab-ı Âli civarında Ebusuud Caddesinde

Numero 72

[H] 1326 [M. 1908] 
درسادت عثا لفلى أجزابى اتشاد جميتى نظامنامهبى

1

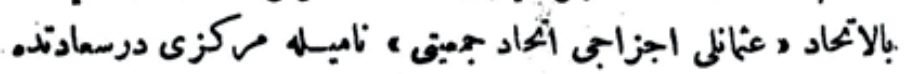

اولمق اوزر• برجعيت تشكيل ايتمشلردر .

\section{جميتك مقاصدى}

Y - غنالملى اجزابى الثحاد جميتنك متصد اساشيسى على المبوم

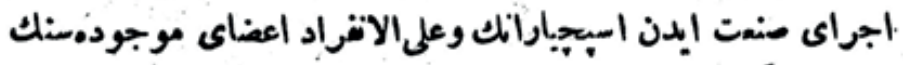

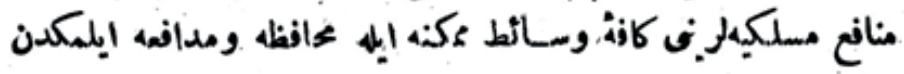
عبارثذر .

شويله S:

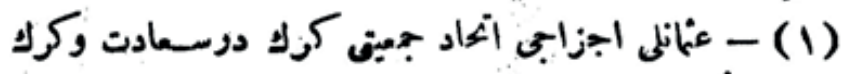

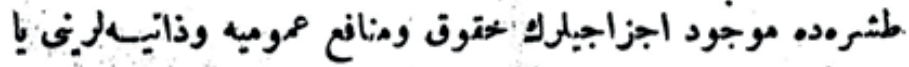

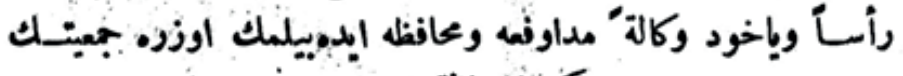

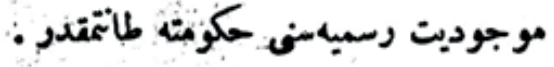

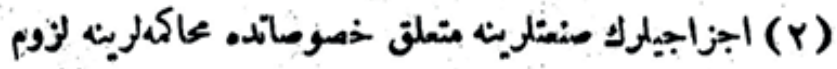

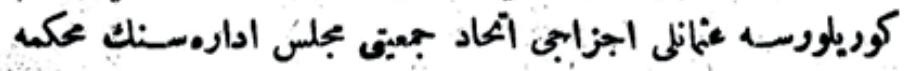

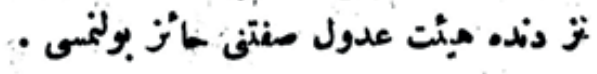




\section{Dersaadet Osmanlı Eczacı İttihad Cemiyeti Nizamnâmesi}

1- Dersaadet eczaciları fi 7 Ağustos sene 324 [20 Ağustos 1908] tarihinde bil-ittihad "Osmanlı Eczacı İttihad Cemiyeti" namıla merkezi Dersaadetde olmak üzere bir cemiyet teşkil etmişlerdir.

\section{Cemiyetin Maksadı}

2- Osmanlı Eczacı İttihad Cemiyetinin maksad-1 esasîsi alelumum icrayı sanat eden ispençiyarânın ve alel-efrâd âzâ-yı mevcudesinin menâfi-i meslekiyelerini kâffe-i vesait-i mümküne ile muhafaza ve müdafaa eylemekten ibarettir.

Şöyle ki:

(1)- Osmanlı Eczacı İttihad Cemiyeti gerek Dersaadet gerek taşrada mevcut eczacıların hukuk ve menâfi-i umûmiye ve zâtiyelerini ya resmen veyahut vekâleten müdafaa ve muhafaza edebilmek üzere cemiyetin mevcudiyet-i resmiyesini hükümete tanıtmakdır.

(2)- Eczacıların sanatlarına müteallik husûsatta muhakemelerine lüzum görülürse Osmanlı Eczacı İttihad Cemiyeti meclis-i idaresinin mahkeme nezdinde heyet-i udûl sıfatına haiz bulunması. 


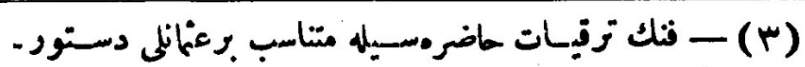

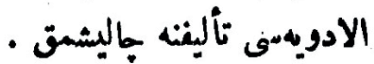

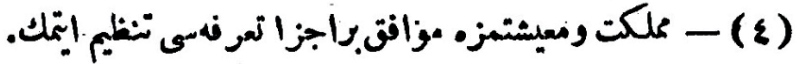

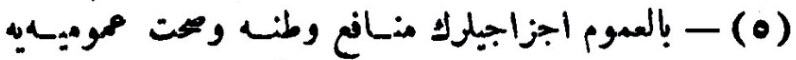

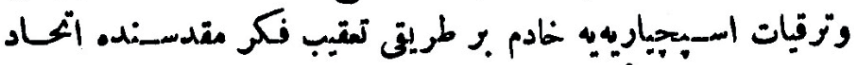

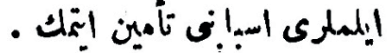

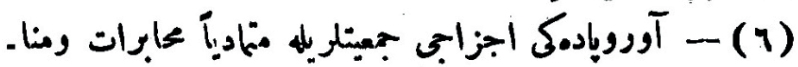

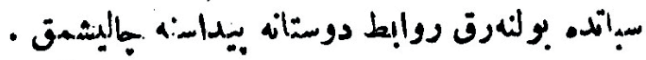

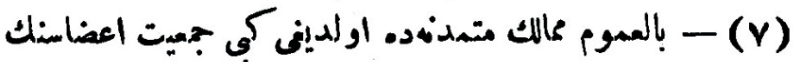

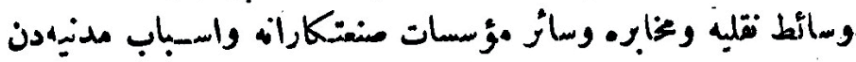

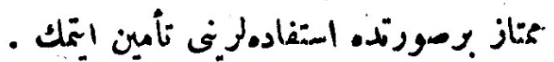

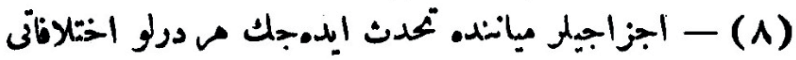

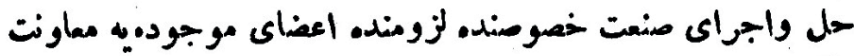
- آتصن

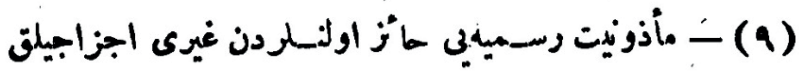
ايدنلرى اجراى صنمتدن منعه جإيشمن .

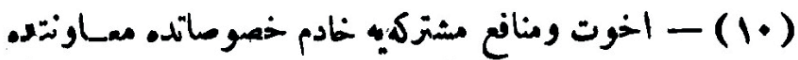

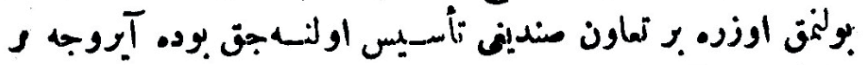

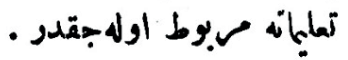

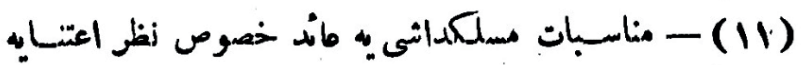

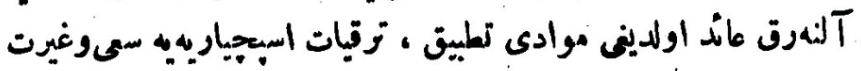

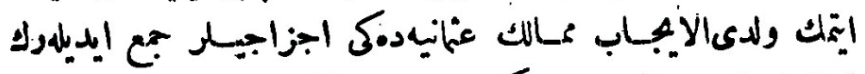

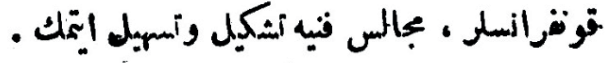


(3)- Fennin terakkiyât-1 hazırasıyla sile mütenasip bir Osmanlı düstûrü'l-edviyesi telifine çalışmak.

(4)- Memleket ve maişetimize muvafik bir ecza tarifesi tanzim etmek.

(5)- Bil-umum eczacıların menâfi-i vatana ve sıhhat-1 umûmiyeye ve terakkiyât-1 ispençiyarîyeye hâdim bir tariki takip fikr-i mukaddesesinde ittihad eylemeleri esbabını temin etmek.

(6)- Avrupadaki eczacı cemiyetleriyle mütemâdiyen muhaberat ve münasebette bulunarak revâbıt-ı dostane peydasına çalışmak.

(7)- Bil-umum memâlik-i mütemeaddinede olduğu gibi cemiyet âzâsının vesait-i nakliye ve muhabere vesair müessesât-1 sanatkârane ve esbab-1 medeniyeden mümtaz bir surette istifadelerini temin etmek.

(8)- Eczacıların meyanında tahaddüs edecek her türlü ihtilâfâtı hal ve icrâ-yı sanat hususunda lüzumunda âzâ-yı mevcudeye muavenet etmek.

(9)- Mezuniyet-i resmiyeye haiz olanlardan gayri eczacılık edenleri icrâ-yı sanattan men'e çalışmak.

(10)- Uhuvvet ve menâfi-i müşterekeye hâdim husûsatta muavenette bulunmak üzere bir teavün sandığı tesis olunacak bu da ayrıca bir talimata merbut olacaktır.

(11)- Münasebet-i meslekdaşiye ait husus nazar-1 itinaya alınarak ait olduğu mevâdd tatbik, terakkiyât-1 ispençiyarîyeye say ve gayret etmek ve lede'l-icâb Memâlik-i Osmaniyedeki eczacılar cem edilerek konferanslar, mecâlis-i fennîye teşkil ve teshil etmek. 


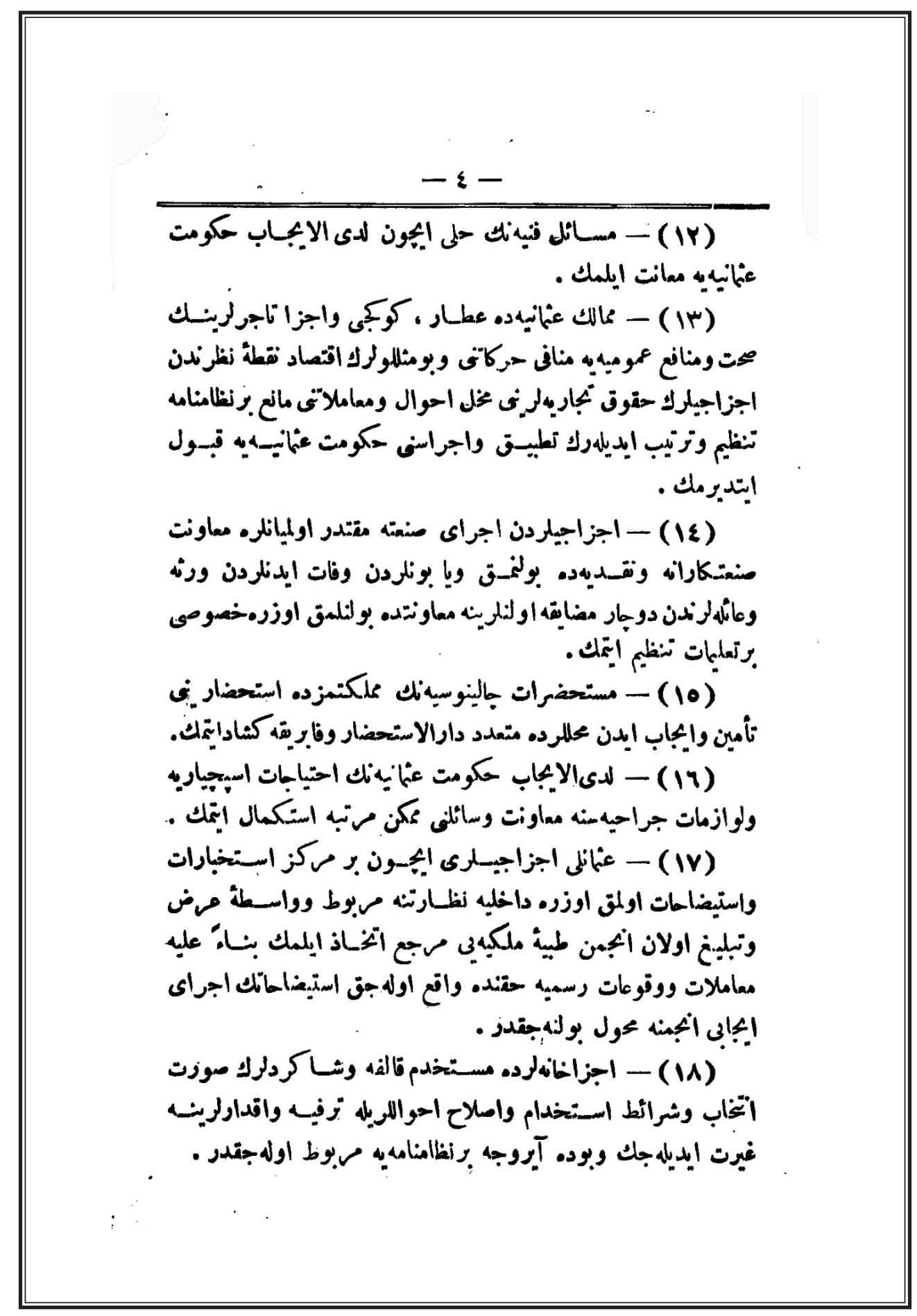


(12)- Mesâil-i fennîyenin halli için lede'l-icâb Hükümet-i Osmaniyeye muavenet eylemek.

(13)- Memâlik-i Osmaniyede attâr, kökçü ve ecza tacirlerinin sıhhat ve menâfi-i umûmiyeye münâfî harekâtına ve bu misillülerin iktisat nokta-i nazarından eczacıların hukuk-1 ticariyelerini muhil ahvâl ve muamelâtını mani bir nizamnâme tanzim ve tertip edilerek tatbik ve icrasını Hükümet-i Osmaniyeye kabul ettirmek.

(14)- Eczacilardan icra-yı sanata muktedir olmayanlara muavenet-i sanatkârane ve nakdiyede bulunmak veya bunlardan vefat edenlerden varise ve ailelerinden dûçar-1 müzâyaka olanlarına muavenette bulunulmak üzere husûsi bir talimat tanzim etmek.

(15)- Müstahzarat-1 calinusiyenin [galenik] memleketimizde istihzarını temin ve icâb eden mahallerde müteaddid darü'l-istihzar ve fabrika küşad etmek.

(16)- Lede'l-icâb Hükümet-i Osmaniyenin ihtiyâcât-1 ispençiyarîye ve levazımât-1 cerrahiyesine muavenet vesailini mümkün mertebe istikmâl etmek.

(17)- Osmanlı eczacıları için bir merkez-i istihbârât ve istihzâhât olmak üzere Dâhiliye Nezâretine merbut ve vasıta-yı arz ve tebliğ olan encâmın Encümen-i T1bbiye-i Mülkiyeyi merci ittihaz eylemek binaenaleyh muamelât ve vukuât-1 resmiye hakkında vaki olacak istîzâhâtın icra-yı icâbı encümene muhavvel bulunacaktır.

(18)- Eczahanelerde müstahdem kalfa ve şakirdlerin suret-i intihâb ve şerâit-i istihdam ve ıslah ahvalleriyle terfiye ve ikdârlarına gayret edilecek ve bu da ayrıca bir nizamnâmeye merbut olacaktır. 


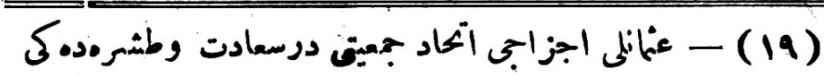

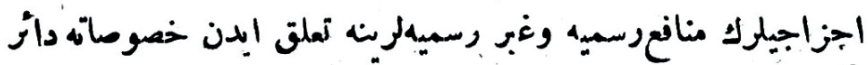

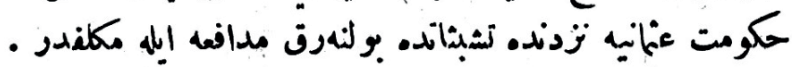

\section{جميتّك تشكيلانى}

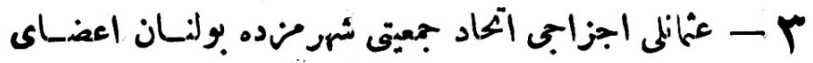

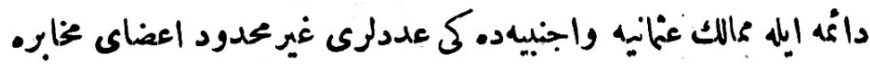

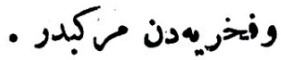

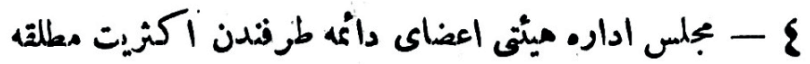

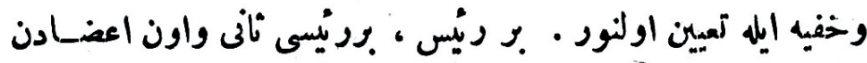

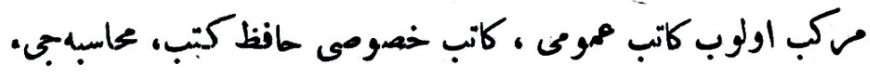

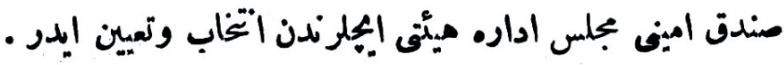

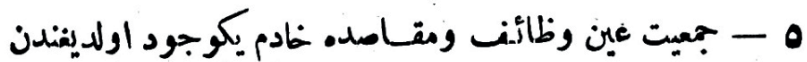

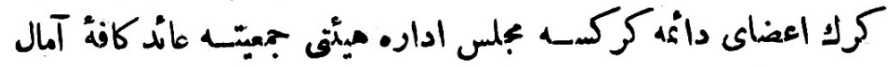

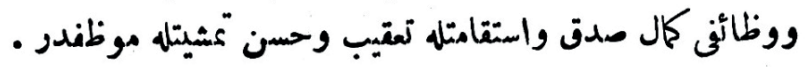

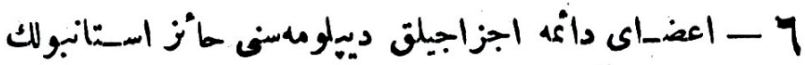
حدودى داخلنده ساكن اجزاجيلردن ، اعضاى مخابوه ولايات عثلانيه

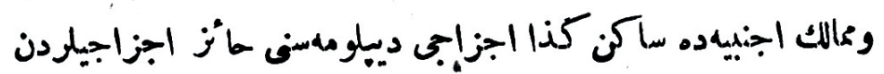

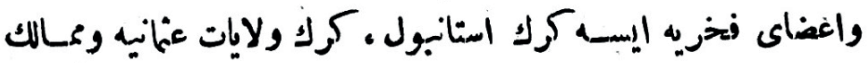

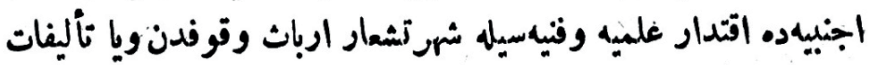


(19)- Osmanlı Eczacı İttihad Cemiyeti Dersaadet ve taşradaki eczacıların menâfi-i resmiye ve gayr-1 resmiyelerine taalluk eden hususâta dair Hükümet-i Osmaniye nezdinde teşebbüsâtda bulunarak müdafaa ile mükelleftir.

\section{Cemiyetin Teşkilatı}

3- Osmanlı Eczacı İttihad Cemiyeti şehrimizde bulunan âzâ-yı dâime ile Memâlik-i Osmaniye ve ecnebiyedeki adetleri gayr-1 mahdut âzâ-y1 muhâbire ve fahriyeden mürekkeptir.

4- Meclis-i idare heyeti âzâ-yı dâime tarafından ekseriyet-i mutlaka ve hafiye ile temin olunur. Bir reis, bir reis-i sânî ve on âzâdan mürekkep olup kâtib-i umûmî, kâtib-i husûsî, hâfız-1 kütüb, muhasebeci, sandık emini meclis-i idare heyeti içlerinden intihap ve tayin eder.

5- Cemiyet aynı vezaif ve makasıda hâdim-i yekvücut olduğundan gerek âzâ-yı dâime gerekse meclis-i idare heyeti cemiyete aid kâffe-i amâl ve vezaifi kemâl-i sadık ve istikametle takip ve hüsn-i temşiyete muzafferdir.

6- Âzâ-yı dâime, eczacılık diplomasına haiz İstanbul'un hudûd-i dâhilinde sakin eczacılardan, âzâ-yı muhâbire vilâyât-1 Osmaniye ve memâlik-i ecnebiyede sakin keza eczacı diplomasına haiz eczacılardan ve âzâ-yı fahriye ise, gerek İstanbul gerek vilayât-1 Osmaniye ve memâlik-i ecnebiyede iktidar-1 ilmiye ve fenniyesiyle şöhretşiâr erbâb-1 vukûftan veya telifât-1 


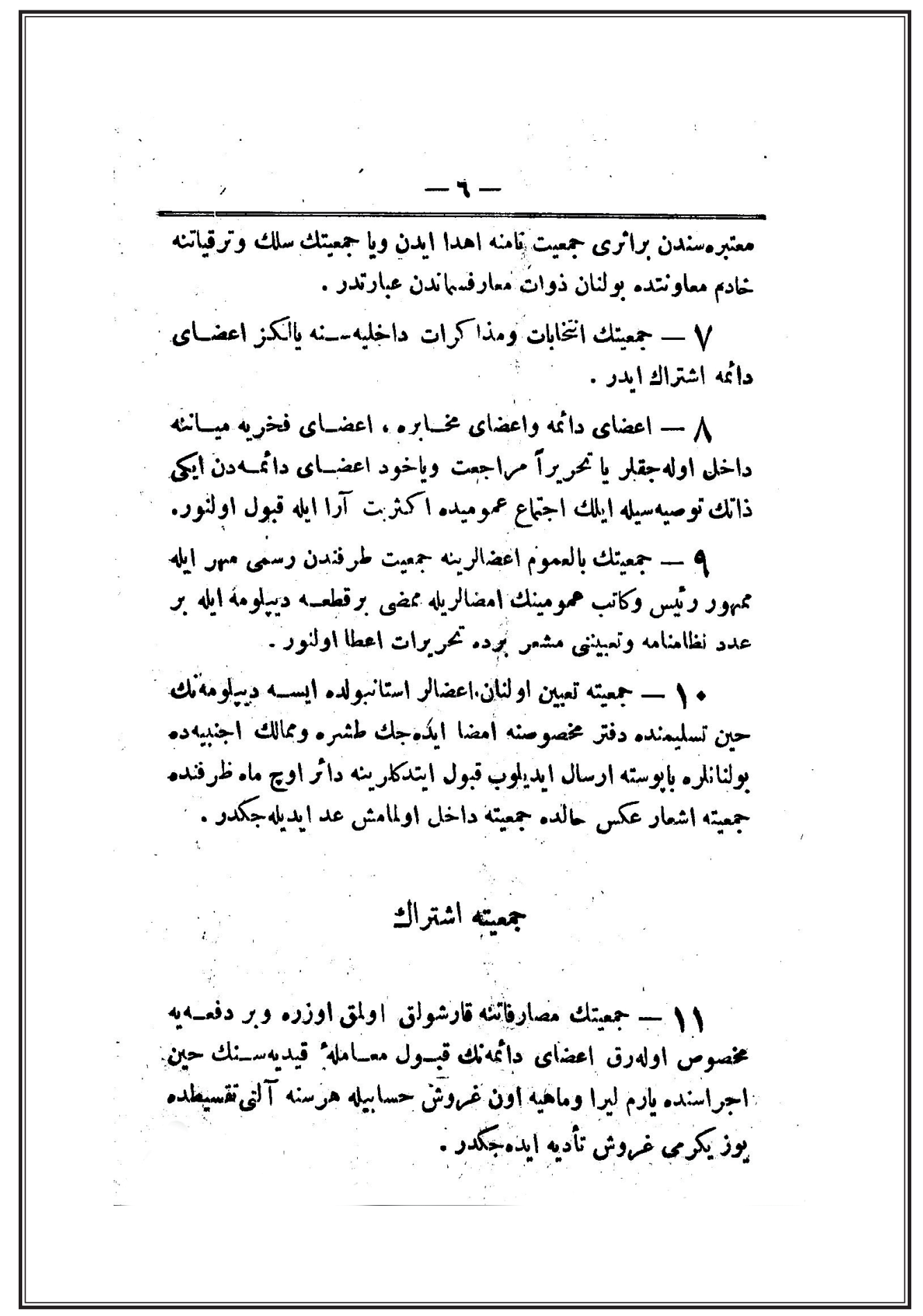


$-6-$

mûteberesinden bir eseri cemiyet namına ihdâ eden veya cemiyetin sülûk ve terakkiyâtına hâdim-i muavenet bulunan zevât-1 maarifândan ibarettir.

7- Cemiyetin intihabât ve müzakerât-1 dâhiliyesine yalnız âzâ-yı dâime iştirak eder.

8- Âzâ-y1 dâime ve âzâ-yı muhâbire, âzâ-yı fahriye meyanına dâhil olacaklar ya tahriren müracaat veyahut âzâ-yı dâimeden iki zatın tavsiyesiyle ilk ictimâ-yı umûmiyede ekseriyet-i ârâ ile kabul olunur.

9- Cemiyetin bil-umum âzâlarına cemiyet tarafından resmî mühür ile memhûr reis ve kâtib-i umûmînin imzalarıyla mümzâ bir kıt'a diploma ile bir adet nizamnâme ve tabiyetini müşir bir de tahrirat ita olunur.

10- Cemiyete tayin olunan âzâlar İstanbul'da ise, diplomanın hîn-1 tesliminde defter-i mahsusuna imza edecek taşra ve memâlik-i ecnebiyede bulunanlara ba-posta irsal edilip kabul ettiklerine dair üç mâh zarfinda cemiyete işâr aksi halde cemiyete dâhil olmamış addedilecektir.

\section{Cemiyete İştirak}

11- Cemiyetin masarifâtına karşılık olmak üzere ve bir defaya mahsus olarak âzâ-yı dâimenin kabul muamele-i kaydiyesinin hîn-1 icrasında yarım lira ve mahiye on kuruş hesabıyla her sene altı taksitte yüz yirmi kuruş tediye edecektir. 


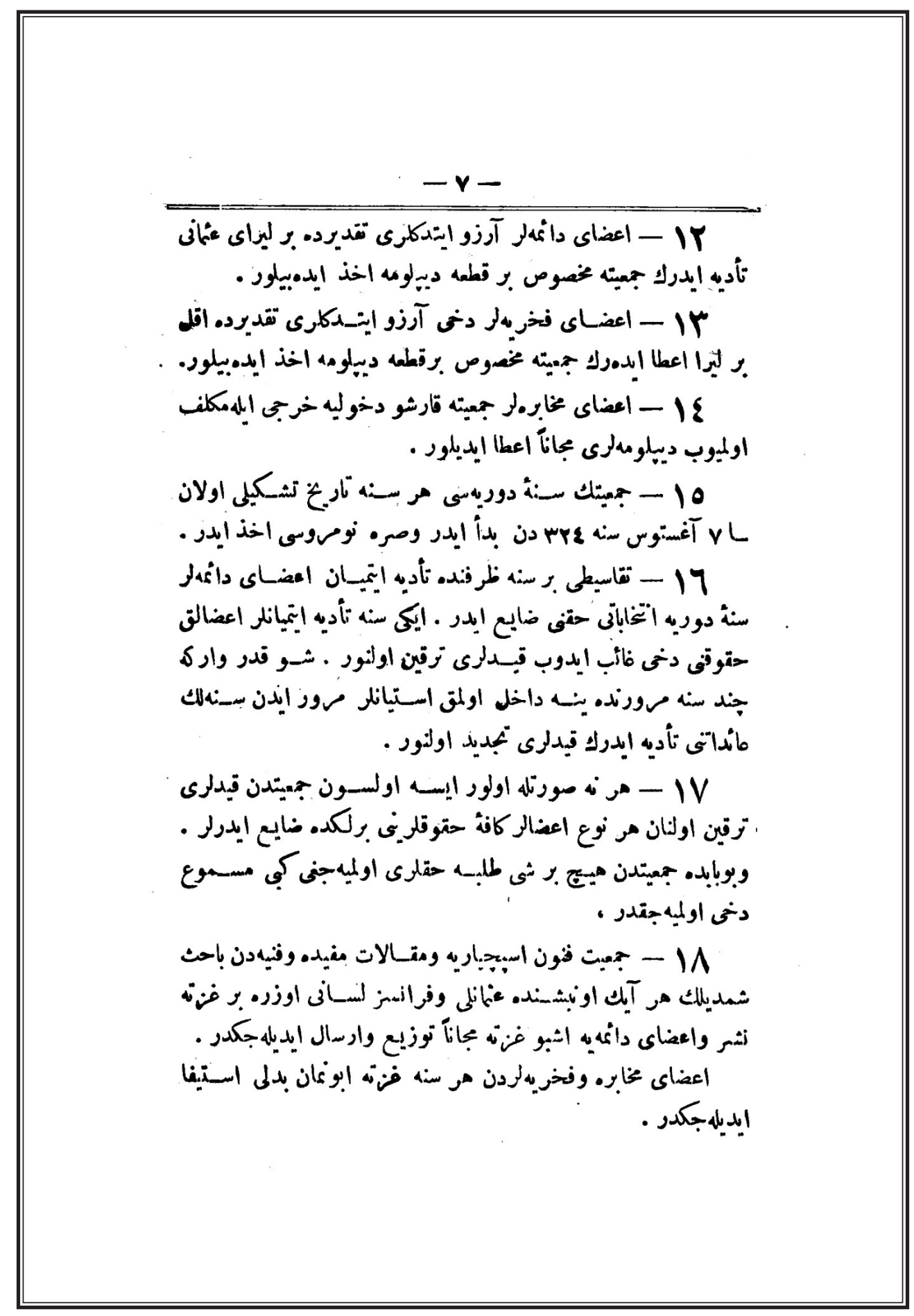


12- Âzâ-yı dâimeler arzu ettikleri takdirde bir lira-yı Osmanî tediye ederek cemiyete mahsus bir kita diploma ahz edebilir.

13- Âzâ-yı fahriyeler dahi arzu ettikleri takdirde akal bir lira itâ ederek cemiyete mahsus bir kita diploma ahz edebilir.

14- Âzâ-yı muhâbireler cemiyete karşı duhûliye harcı ile mükellef olmayıp diplomaları meccanen itâ edilir.

15- Cemiyetin sene-i devriyesi her sene tarih-i teşkili olan fi 7 Ağustos sene 324den bed eder ve sira numarasi ahz eder.

16- Tekasiti bir sene zarfında tediye etmeyen âzâ-yı dâimeler sene-i devriye intihabâtı hakkını zayi eder. İki sene tediye etmeyenler âzâlık hukukunu dahi kaybedip kayıtları terkin olunur. Şu kadar var ki çend sene mürûrunda yine dâhil olmak isteyenler mürûr eden senelik aidatını tediye ederek kayıtları tecdit olunur.

17- Her ne surette olur ise olsun cemiyetten kayıtları terkin olunan her nevi âzâlar kâffe hukuklarını birlikte zayi ederler. Ve bu bâbda cemiyetten hiçbir şey talep hakları olmayacağı gibi mesmû dahi olmayacaktır.

18- Cemiyet, fünûn-1 ispençiyarîye ve makalât-1 müfide ve fenniyeden bahis şimdilik her ayın on beşinde Osmanlı ve Fransız lisanı üzere bir gazete neşr ve âzâ-yı dâimeye işbu gazete meccanen tevzi ve irsal edilecektir. Âzâ-yı muhâbire ve fahriyelerden her sene gazete abonman bedeli istifa edilecektir. 


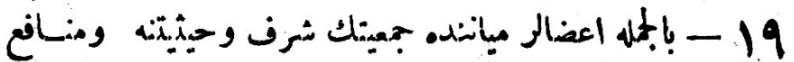

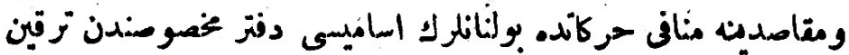

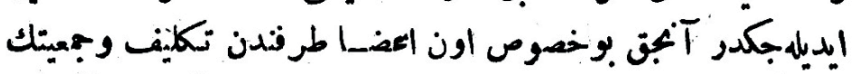

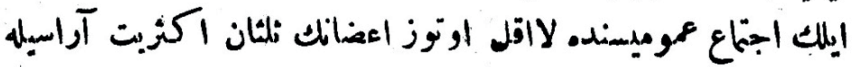

هئت اداره وظافُى

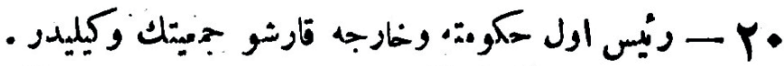

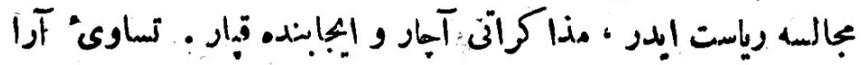

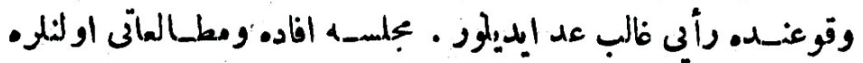

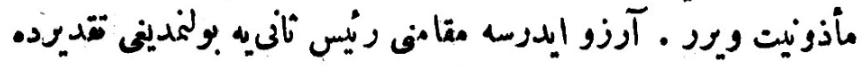

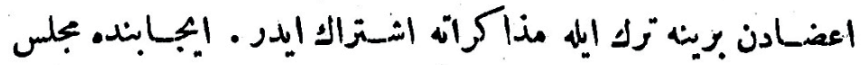

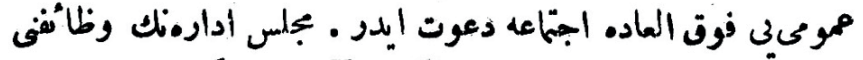

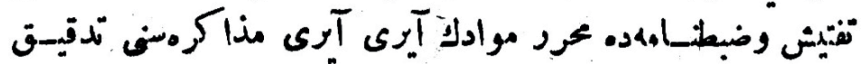

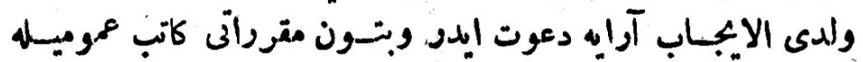

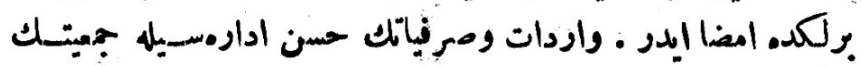

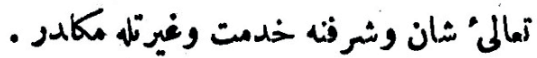

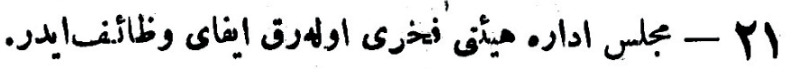

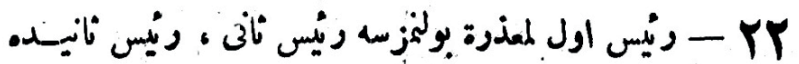

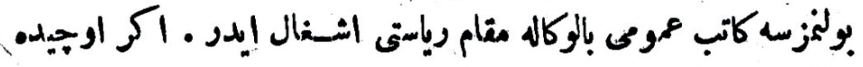

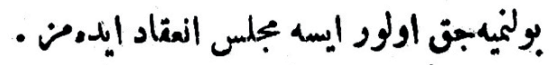


19- Bilcümle âzâlar meyanında cemiyetin şeref ve haysiyetine ve menâfi ve makasıdına münâfî harekette bulunanların esâmisi defter-i mahsusadan terkin edilecektir ancak bu husus on âzâ tarafindan teklif ve cemiyetin ilk ictima-yı umûmiyesinde lâakal otuz âzânın sülüsan ekseriyet-i ârâsıyla icra olunacaktır.

\section{Heyet-i İdare Vezaifi}

20- Reis-i evvel hükümete ve harice karşı cemiyetin vekilidir. Meclise riyaset eder. Müzakerâtı açar ve icabında kapar. Tesavi-yi ârâ vukuunda reyi galip addedilir. Meclise ifade ve mütalaâtı olanlara mezuniyet verir. Arzu ederse makamını reis-i sânîye bulunmadığı takdirde âzâdan birine terk ile müzakerâta iştirak eder. İcabında meclis-i umûmiyi fevkalâde ictimaa davet eder. Meclis-i idarenin vezaifini teftiş ve zabıtnamede muharrer mevâddın ayrı ayrı müzakeresini tedkik ve lede'l-icâb ârâya davet eder. Ve bütün mukarreratı kâtib-i umûmiyle birlikte imza eder. Varidat ve sarfiyatın hüsn-i idaresiyle cemiyetin taâlî-i şan ve şerefine hidmet ve gayretle mükellefdir.

21- Meclis-i idare heyeti fahri olarak ifa-y1 vazife eder.

22- Reis-i evvel mazuren bulunmazsa reis-i sânî, reis-i sânî de bulunmazsa kâtib-i umûmî bilvekâle makam-1 riyaseti işgal eder. Eğer üçü de bulunmayacak olur ise meclis inikat edemez. 


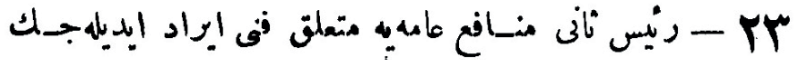

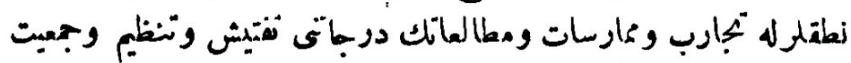

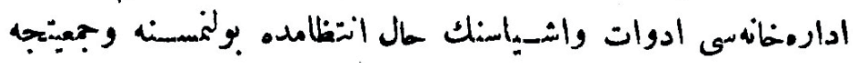

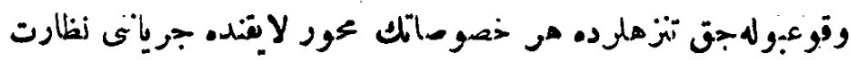

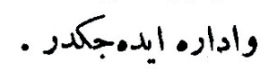

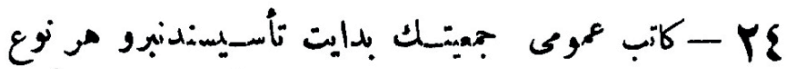

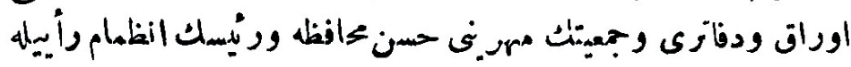

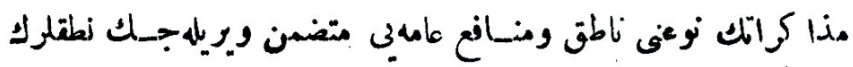

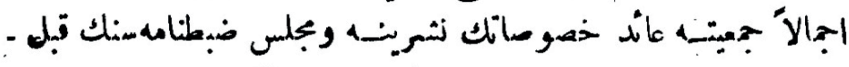

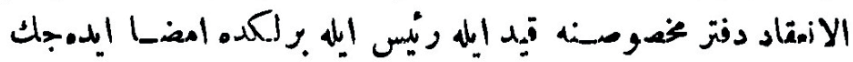

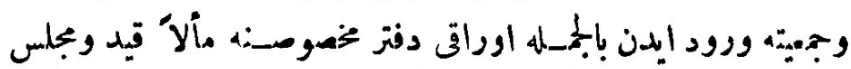

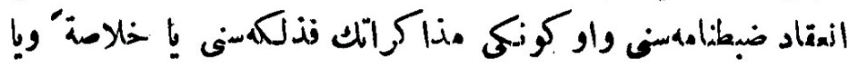

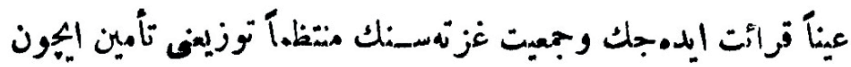

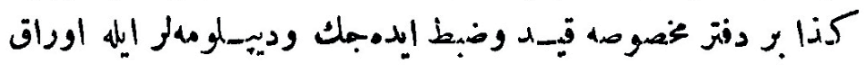

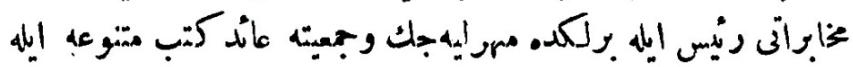

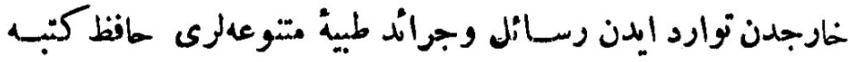

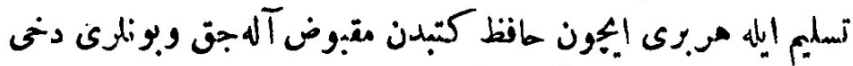

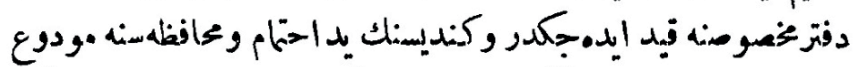

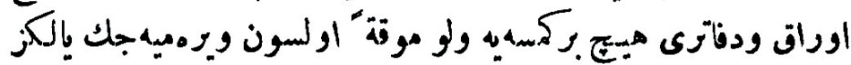

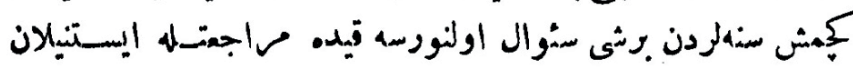

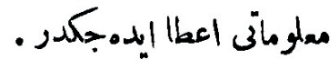

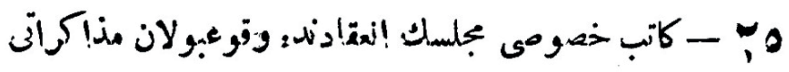


23- Reis-i sânî menâfi-i ammeye müteallik fenni irat edilecek nutuklarla tecârüb ve mümeresat ve mütâlaatın derecâtını teftiş ve tanzim ve cemiyetin idarehanesi edevat ve eşyasının hal-i intizamda bulunmasına ve cemiyetçe vuku bulacak tenezzühlerde her hususâtın mihver-i layıkında cereyanı nezâret ve idare edecektir.

24- Kâtib-i umûmî cemiyetin bidayet-i tesisinden beri her nevi evrak ve defteri, cemiyetin mührünü hüsn-i muhafaza ve reisin inzimâm-1 reyiyle müzakerâtın nevini natık ve menâfi-i ammeyi mütazammın verilecek nutukların icmalen cemiyete ait hususâtın neşrine ve meclis zabitnamesinin kable'l-inikat defter-i mahsusuna kayd ile reis ile birlikte imza edecek ve cemiyete vürûd eden bilcümle evrakı defter-i mahsusuna mealen kayıt ve meclis inikat zabitnamesini ve o günkü müzakerâtın fezlekesini ya hülasaten veya aynen kıraat edecek ve cemiyet gazetesinin muntazaman tevziini temin için keza bir defter-i mahsusa kayıt ve zabt edecek ve diplomalar ile evrak muhaberatını reis ile birlikte mühürleyecek ve cemiyete ait kütüb-i mütenevvia ile hariçten tevârüt eden resail ve ceraid-i tıbbiye-i mütenevviaları hâfız-1 kütübe teslim ile her biri için hâfız-1 kütübden makbuz alacak ve bunları dahi defter-i mahsusuna kayd edecektir ve kendisinin yed-i ihtimam ve muhafazasına mevdû evrak ve defâtiri hiçbir kimseye velev muvakkaten olsun veremeyecek yalnız geçmiş senelerden bir şey sual olunursa kayda müracaatla istenilen malûmatı itâ edecektir.

25- Kâtib-i husûsî meclisin inikatında vuku bulan müzakerâtı 


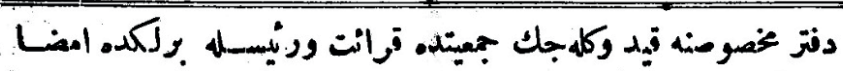

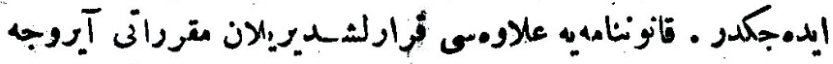

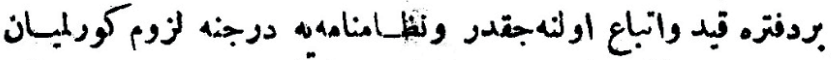

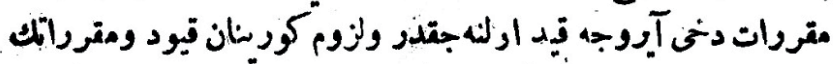

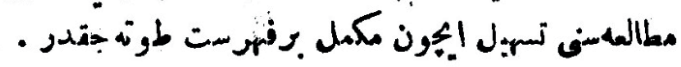

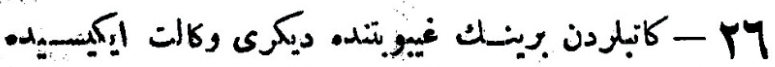

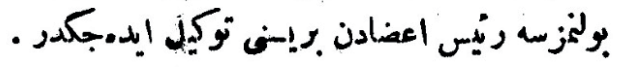
- YV

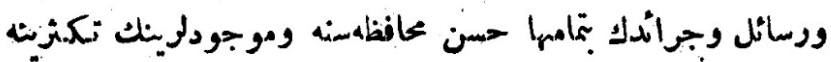

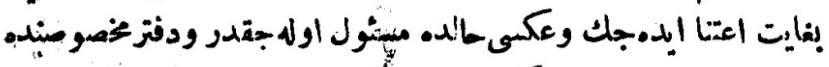

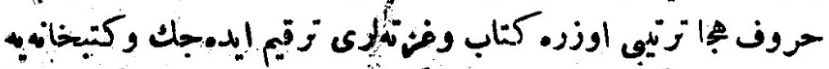

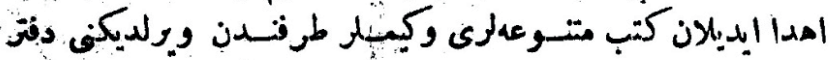

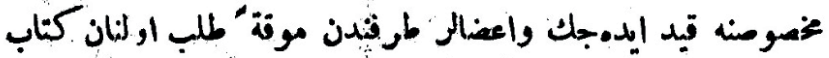

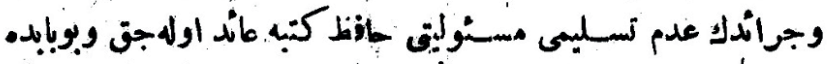

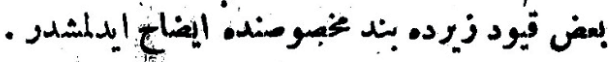

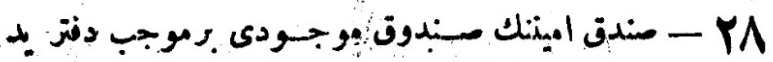

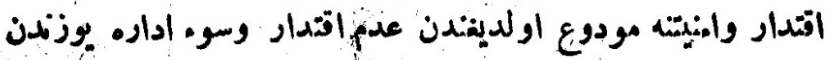

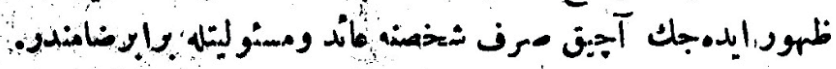

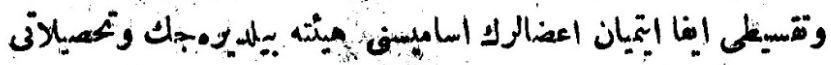

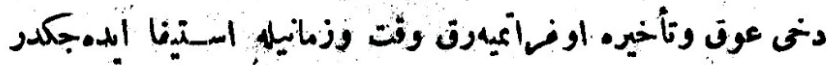

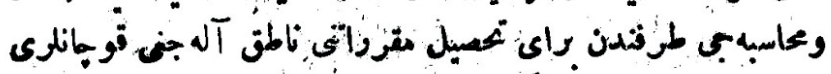

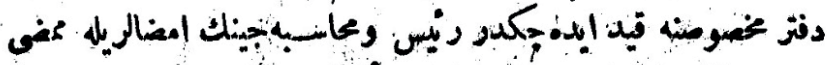

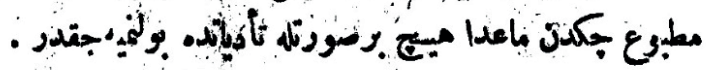


defter-i mahsusuna kayd ve gelecek cemiyette k1raat ve reisle birlikte imza edecektir. Kanunnameye ilavesi kararlaştırılan mukarreratı ayrıca bir deftere kayd ve ittiba olunacaktır ve nizamnâmeye dercine lüzum görülmeyen mukarrerat dahi ayrıca kayd olunacaktır ve lüzum görünen kuyud ve mukarreratın mütâlaasını teshil için mükemmel bir fihrist tutacaktır.

26- Kâtiplerden birinin gaybûbetinde diğeri vekâlet, ikisi de bulunmazsa reis âzâdan birini tevkil edecektir.

27- Hâfiz-1 kütüp kütüphanede mevcut ber-mûcib liste kitap ve resâil ve cerâidin bi-tamamiha hüsn-i muhafazasına ve mevcutlarının teksirine begayet itina edecek ve aksi halde mesul olacaktır ve defter-i mahsusunda hurûf-1 hece tertibi üzere kitap ve gazeteleri terkim edecek ve kütüphaneye ihda edilen kütüb-i mütenevviaları ve kimler tarafından verildiğini defter-i mahsusuna kayıt edecek ve âzâlar tarafindan muvakkaten talep olunan kitap ve cerâidin adem-i teslimi mesuliyeti hâfız-1 kütübe ait olacak ve bu bâbda bazı kuyûd zîrde bend-i mahsusunda izah edilmiştir.

28- Sandık emininin sandık mevcudu ber-mûcib-i defter yedd-i iktidar ve emniyetine mevdû olduğundan âdem-i iktidar ve sûi idare yüzünden zuhur edecek açık, sırf şahsına ait ve mesuliyetle beraber zâmindir. Ve taksidi ifa etmeyen âzâların esâmisini heyete bildirecek ve tahsilatı dahi avk ve tehire uzatmayarak vakit ve zamanıyla istifa edecektir ve muhasebeci tarafından berây-1 tahsil mukarreratı nâtık alacağı koçanları defter-i mahsusuna kayıt edecektir reis ve muhasebecinin imzalarıyla mümza matbu çekinden mâadâ hiçbir suretle tediyatta bulunmayacaktır. 
- Yq

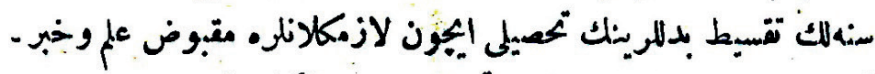

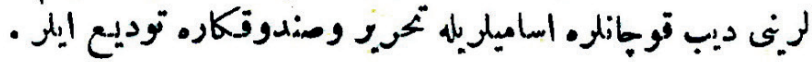

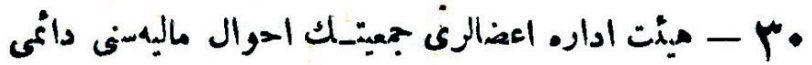

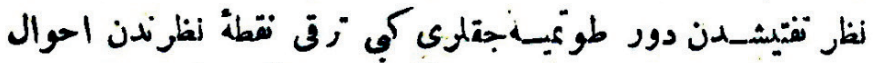

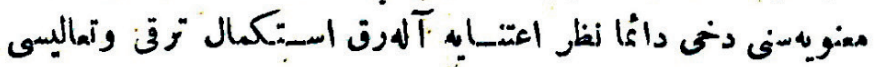

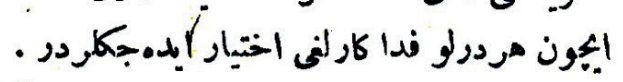

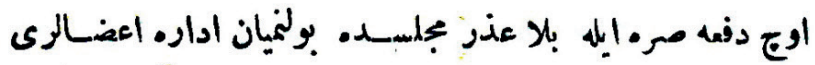

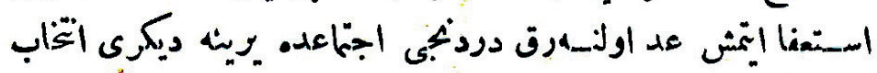

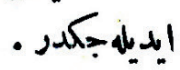

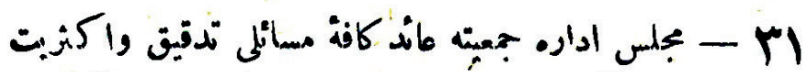

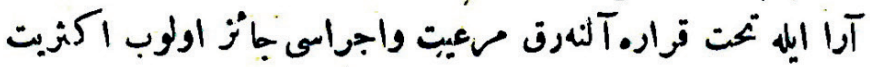

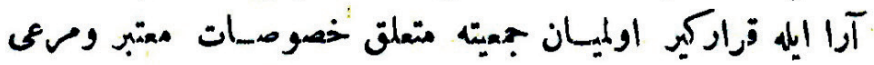

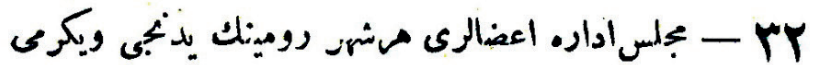

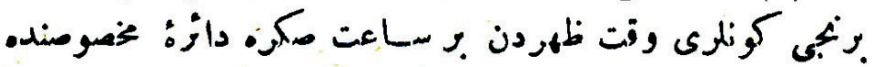

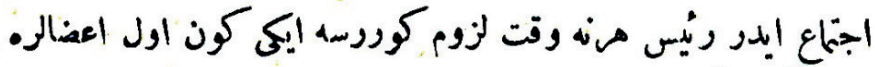

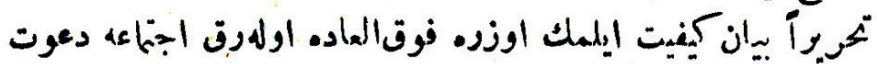

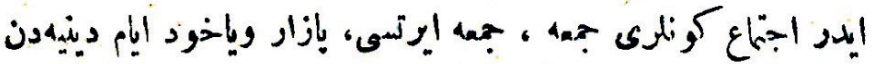

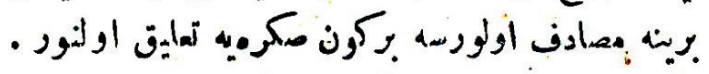

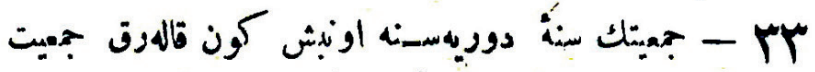

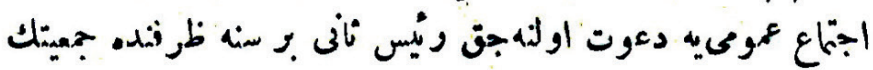


29- Muhasebeci, defter-i mahsus mûcibince diploma harciyla senelik taksit bedellerinin tahsili için lazım gelenlere makbuz ilmühaberlerinin dip koçanlara esâmileriyle tahrir ve sandukkâra tevdi eyler.

30- Heyet-i idare âzâları cemiyetin ahval-i maliyesini daima nazâr-1 teftişinden dûr tutmayacakları gibi terakki nokta-yı nazarından ahvâl-i maneviyesini dahi daima nazar-ı itinaya alarak istikmâl-i terakki ve tealisi için her türlü fedakârlığı ihtiyar edeceklerdir.

Üç defa sırayla bilâ-özr mecliste bulunmayan idare âzâları istifa etmiş addolunarak dördüncü içtimada yerine diğeri intihabp edilecektir.

31- Meclis-i idare cemiyete ait kâffe-i mesaili tedkik ve ekseriyet-i ârâ ile taht-ı karara alınarak meriyet ve icrası caiz olup ekseriyet-i ârâ ile karagîr olmayan cemiyete müteallik hususât muteber ve meri olamaz.

32- Meclis-i idare âzâları her şehr-i rumînin yedinci ve yirmi birinci günleri vakt-i zuhrdan bir saat sonra daire-i mahsusta içtimai eder. Reis her ne vakit lüzum görürse iki gün evvel âzâlara tahriren beyan-1 keyfiyet eylemek üzere fevkalâde olarak ictimaya davet eder ictima günleri Cuma, Cumartesi, Pazar veyahut eyyam-1 diniyeden birine müsâdif olursa bir gün sonraya tâlik olunur.

33- Cemiyetin sene-i devriyesine on beş gün kalarak cemiyet ictima-y1 umûmiye davet olunacak reis-i sânî bir sene zarfinda cemiyetin 


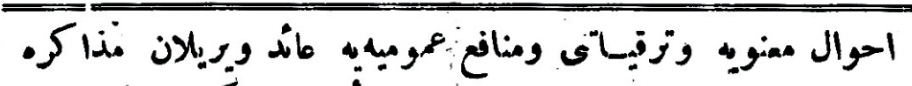

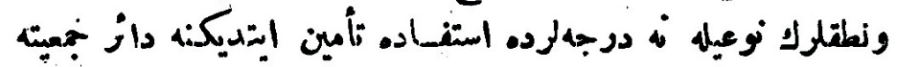

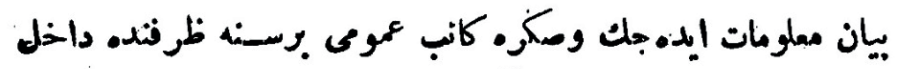

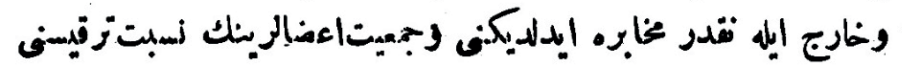

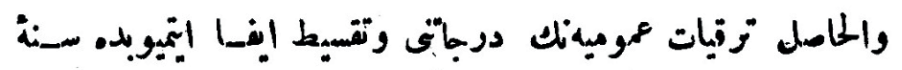

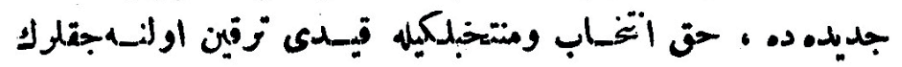

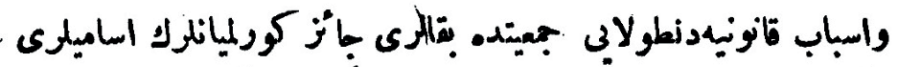

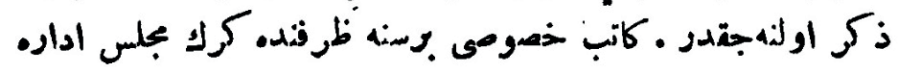

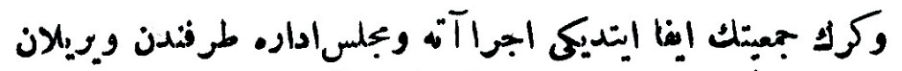

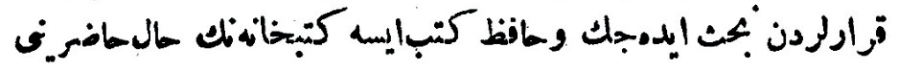

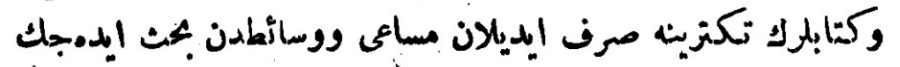

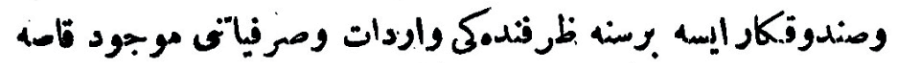

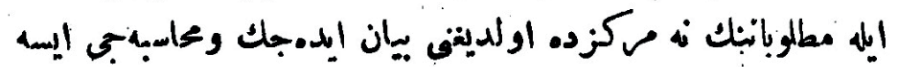

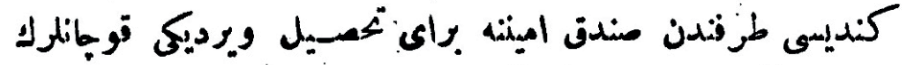

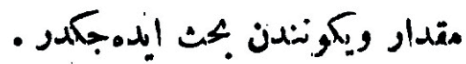

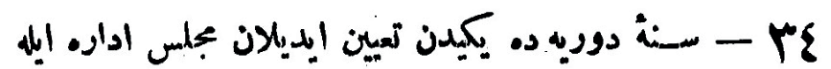

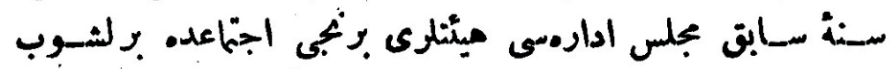

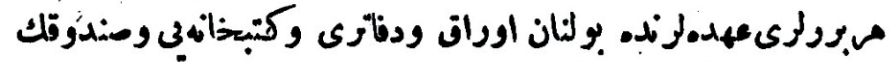

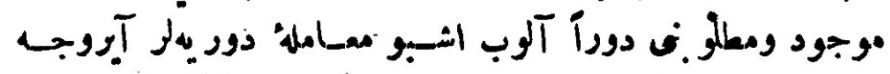

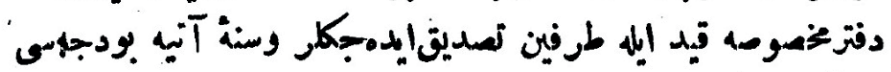

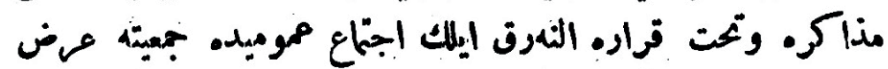

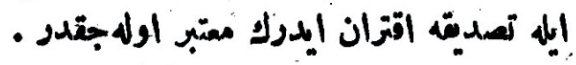


ahval-i maneviye ve terakkiyâtı ve menâfi-i umûmiyeye ait verilen müzâkere ve nutukların neviyle ne derecelerde istifade temin ettiğine dair cemiyete beyan-1 malumat edecek ve sonra kâtib-i umûmî bir sene zarfinda dahil ve hariç ile ne kadar muhabere edildiğini ve cemiyet âzâlarının nisbet-i terakkisini velhasıl terakkiyât-1 umûmiyenin derecâtını ve taksit ifa etmeyip de sene-i cedîdede hakk-1 intihâb ve müntehablığıyla kaydı terkin olunacakların ve esbâb-1 kanunîyeden dolayı cemiyette bekaları haiz görülmeyenlerin esâmileri zikr olunacaktır. Kâtib-i husûsî bir sene zarfında gerek meclis-i idare ve gerek cemiyetin ifa ettiği icraata ve meclis-i idare tarafindan verilen kararlardan bahsedecek ve hâfız-1 kütüb ise kütüphanenin hal-i hâzırını kitapların teksirine sarf edilen mesai ve vesaitten bahsedecek ve sandukkâr ise bir sene zarfindaki varidat ve sarfiyatını mevcut kasa ile matlubatının ne merkezde olduğunu beyan edecek ve muhasebeci ise kendisi tarafindan sandık eminine berây-1 tahsil verdiği koçanların miktar ve yekûnundan bahsedecektir.

34- Sene-i devriyede yeniden tayin edilen meclis-i idare ile sene-i sabık meclis-i idaresi heyetleri birinci içtimada birleşip her birileri uhdelerinde bulunan evrak ve defatiri ve kütüphaneye ve sandığın mevcut ve matlubunu devren alıp işbu muamele-i devriyeleri ayrıca defter-i mahsusa kayıt ile tarafeyn tasdik edecekler ve sene-i atiye bütçesi müzakere ve taht-1 karara alınarak ilk ictima-yı umûmiyede cemiyete arz ile tasdike iktiran ederek muteber olacaktır. 


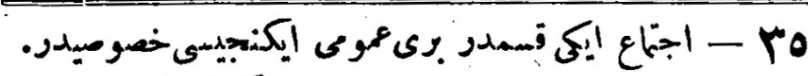

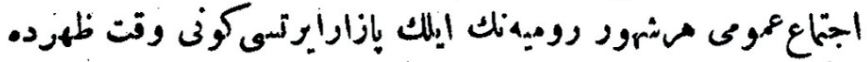

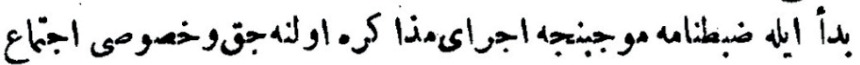

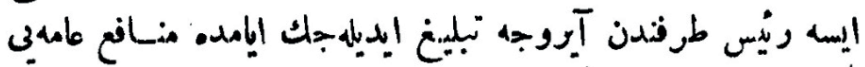

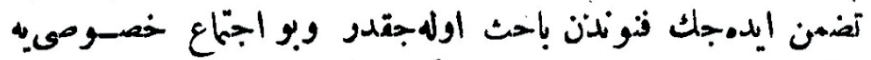

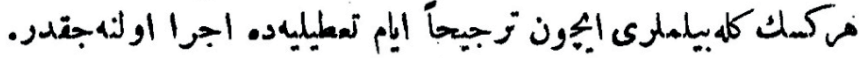

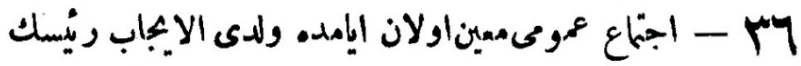

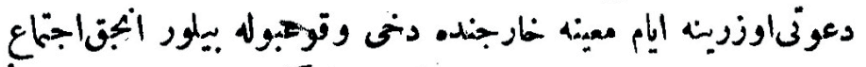

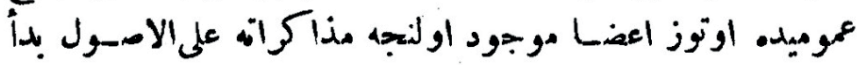
واتخاذ مقرواته صلاحيتداردر ـ اعند

اعن - MV.

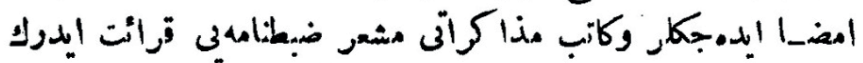

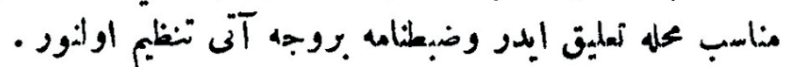

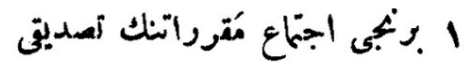

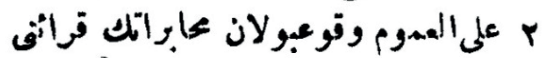

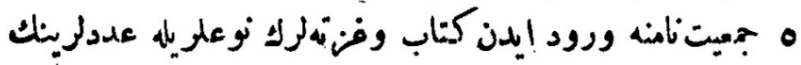
. ع هئت اداره اعضـا وقوميسـيون طرفلمندن وقوعبـولان تكملفات وسؤاللر

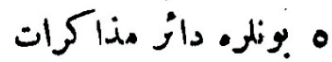

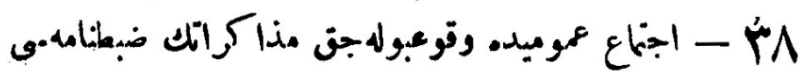

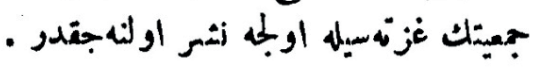


35- İctima iki kısımdır, biri umûmî ikincisi husûsîdir. İctima-yı umûmî her şühur-i rumiyenin ilk pazartesi günü vakt-i zuhrda bed ile zabitnâme mucibince icra-yı müzakere olunacak ve husûsî içtima ise reis tarafından ayrıca tebliğ edilecek eyyamda menâfi-i ammeyi tazmin edecek fünûndan bahis olacaktır ve bu içtima-yı hususiye herkesin gelebilmeleri için tercihen eyyam-1 tatiliyede icra olunacaktır.

36- İctima-y1 umûmî muayyen olan eyyamda ve lede'l-icab reisin daveti üzerine eyyam-1 muayyene haricinde dahi vuku bulabilir ancak ictima-i umûmiyede otuz âzâ mevcut olunca müzakerâta alelusul bed ve ittihâz-1 mukarrerata salahiyettardır.

37- Her icçtima-i umûmiyede mevcut olan âzâlar defter-i mahsusa imza edecekler ve kâtip müzakerâtı müşir zabıtnameyi kıraat ederek münasip mahalle talik eder ve zabıtname ber-vech-i âti tanzim olunur.

1- Birinci icçtima' mukarreratının tasdiki

2- Alelumum vuku bulan muhaberatın kıraatı

3- Cemiyet namına vürûd eden kitap ve gazetelerin nevileriyle adetlerinin beyanı

4- Heyet-i idare âzâ ve komisyon taraflarından vuku bulan teklifat ve sualler

\section{5- Bunlara dair müzakerât}

38- İctima-i umûmiyede vuku bulacak müzakerâtın zabıtnamesi cemiyetin gazetesiyle evvelce neşrolunacaktır. 


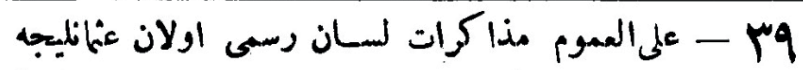

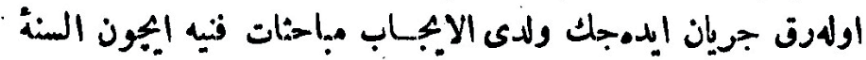

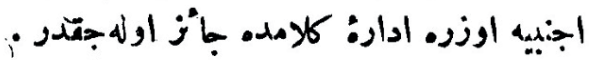

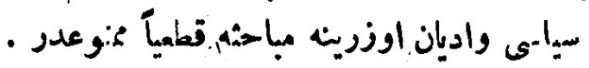

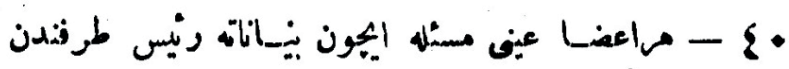

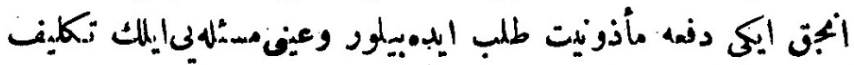

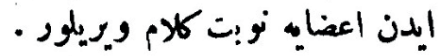

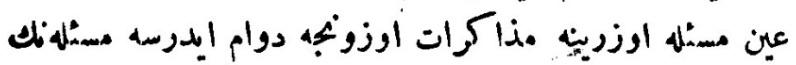

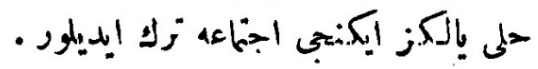

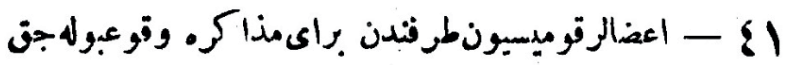

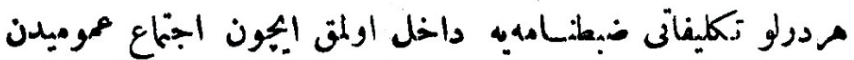

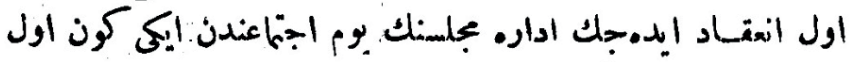

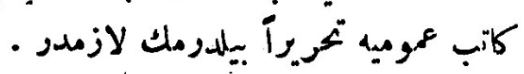

Y

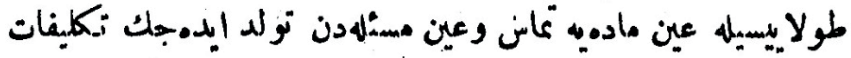

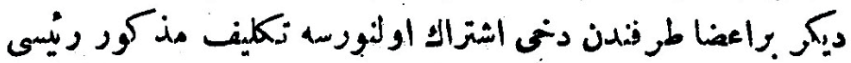

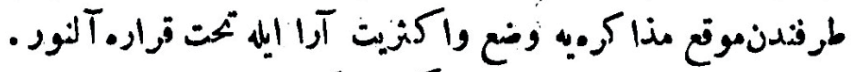

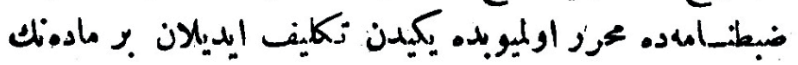

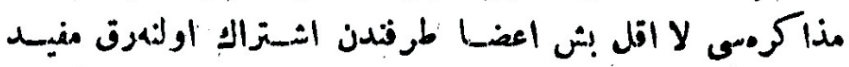

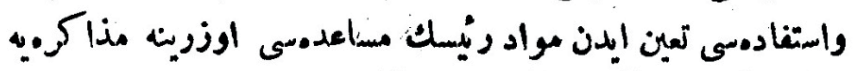

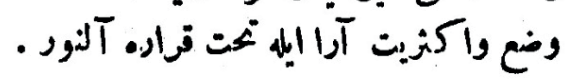
بع - اولكى اجتماعلردة مهيق أصـديق ابديلان بوقرارك 
39- Alelumum müzakerât lisan-1 resmi olan Osmanlıca olarak cereyan edecek ve lede'l-icab mebahisât-1 fenniye için elsine-1 ecnebiye üzere idare-i kelâm da caiz olacaktır.

Siyasi ve edyan üzerine mübahese katiyen memnudur.

40- Her âzâ aynı mesele için beyanata reis tarafindan ancak iki defa mezuniyet talep edebilir ve aynı meseleyi ilk teklif eden âzâya nevbet-i kelâm verilir.

Aynı mesele üzerine müzakerât uzunca devam ederse meselenin halli yalnız ikinci ictimaa terk edilir.

41- Âzâlar komisyon tarafından berây-ı müzakere vuku bulacak her türlü teklifâtı zabıtnameye dâhil olmak için ictima-yı umûmiyeden evvel inikat edecek idare meclisinin yev-i ictimandan iki gün evvel kâtib-i umûmiye tahriren bildirmek lâzımdır.

42- İctima-y1 umûmiyede bir meselenin müzakerâtı esnasında dolayısıyla aynı maddeye temas ve aynı meseleden tevellüt edecek teklifat diğer bir âzâ tarafindan dahi iştirak olunursa teklif-i mezkûr reis tarafından mevki-i müzakereye vaz ve ekseriyet-i ârâ ile taht-ı karara alınır.

Zabıtnâmede muharrer olmayıp da yeniden teklif edilen bir maddenin müzakeresi lâakal beş âzâ tarafından iştirak olunarak müfid ve istifadesi taayyün eden mevâdd reisin müsaadesi üzerine müzakereye vâz ve ekseriyet-i ârâ ile taht-1 karara alınır.

43- Evvelki içtimalarda meriyeti tasdik edilen bir kararın 


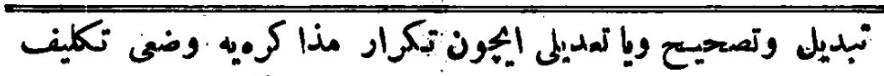

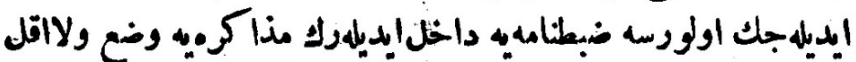

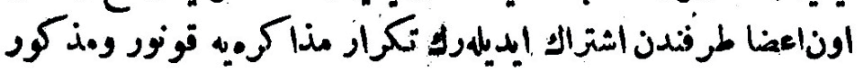

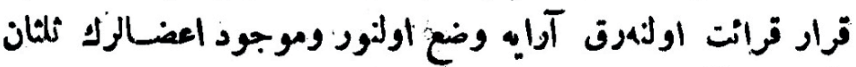

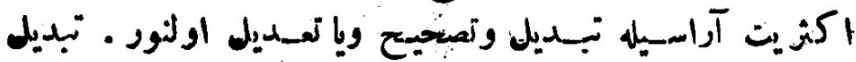

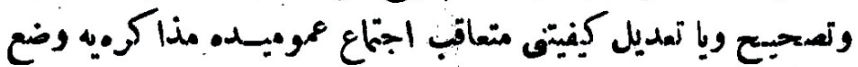

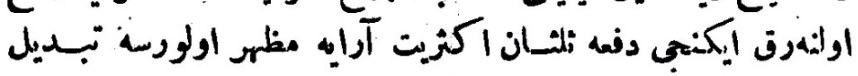

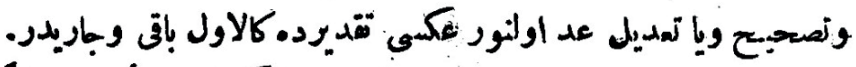

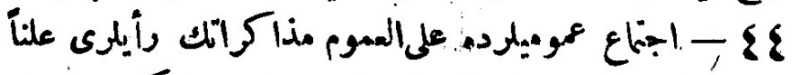

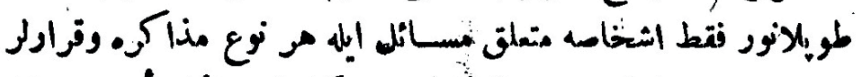

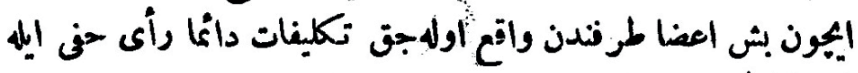

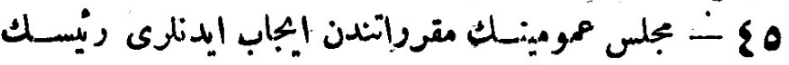

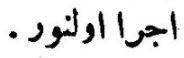

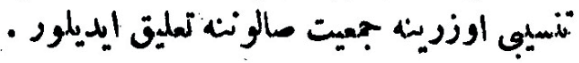

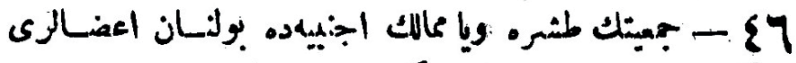

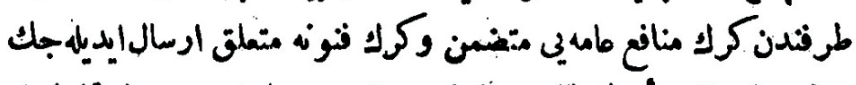

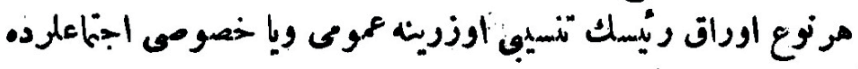

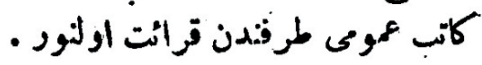

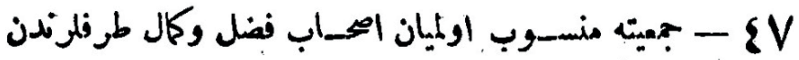

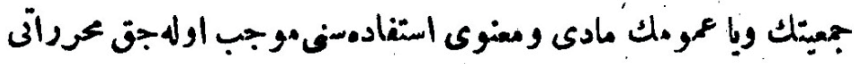

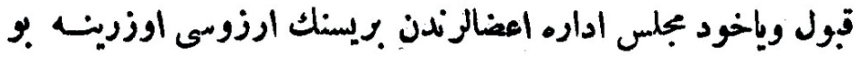

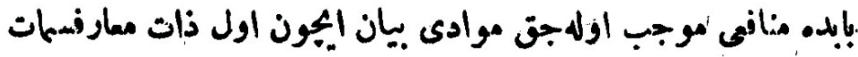

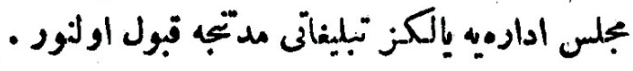


tebdil ve tashih veya tadil için tekrar müzakereye vazı teklif edilecek olursa zabitnâmeye dahil edilerek müzakereye vaz ve lâakal on âzâ tarafından iştirak edilerek tekrar müzakereye konur ve mezkur karar kıraat olunarak ârâya vaz olunur ve mevcut âzâların sülüsan ekseriyet-i ârâsıyla tebdil ve tashih veya tadil olunur. Tebdil ve tashih veya tadil keyfiyetini ve müteakip ictima-yı umûmiyede müzakereye vaz olunarak ikinci defa sülüsan ekseriyet-i ârâya müzahir olursa tebdil ve tashih veya tadil addolunur aksi takdirde kal-1 evvel bâki ve carîdir.

44- İctima-yı umûmiyelerde alelumum müzakerâtın reyleri alenen toplanır fakat eşhasa müteallik mesail ile her nevi müzakere kararları için beş âzâ tarafından vaki olacak teklifât daima rey-i hafî ile icra olunur.

45- Meclis-i umûmiyenin mukarreratından icap edenleri reisin tensibi üzerine cemiyet salonuna talik edilir.

46- Cemiyetin taşra veya memalik-i ecnebiyede bulunan âzâları tarafından gerek menâfi-i ammeye mutazammın ve gerek fünûna müteallik irsal edilecek her nevi evrak reisin tensibi üzerine umûmî veya husûsî ictimalarda kâtib-i umûmî tarafından kıraat olunur.

47- Cemiyete mensup olmayan eshab-1 fazl ü kemâl tarafindan cemiyetin veya umûmun maddi ve manevi istifadesini mûcib olacak muharrerâtı kabul veyahut meclis-i idare âzâlarından birisinin arzusu üzerine bu bâbda menâfi mûcib olacak mevâddı beyan için zât-1 maarifsimât meclis-i idareye yalnız tebligatı müddetince kabul olunur. 


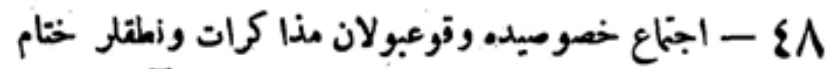

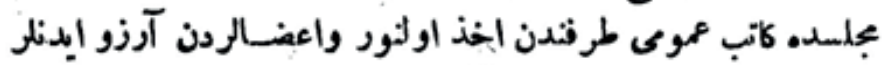

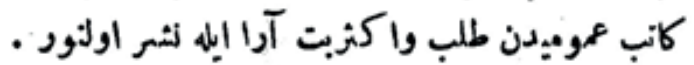

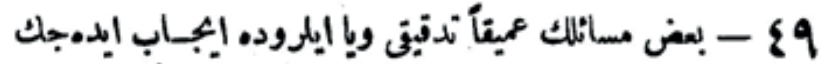

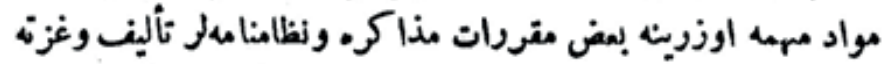

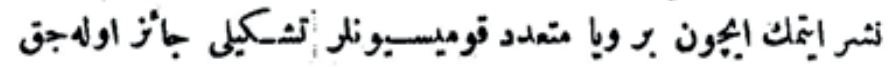

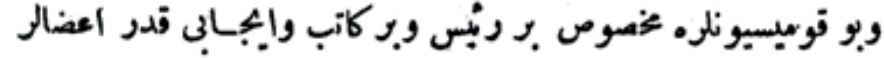

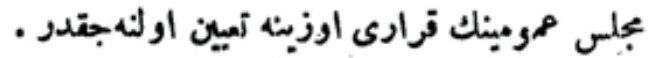

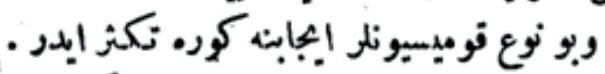

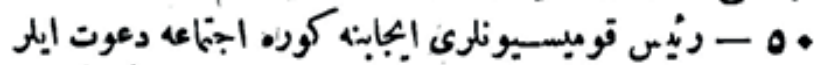

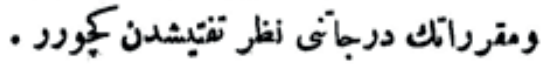

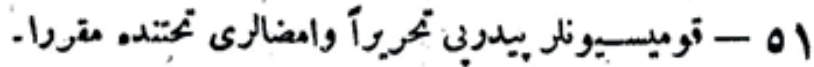

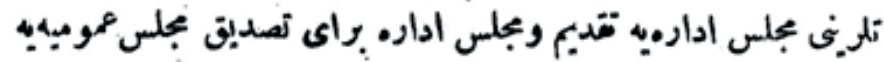
مرض ايدر .

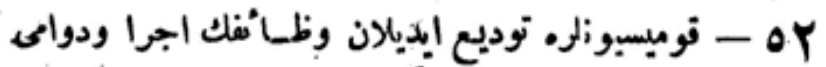

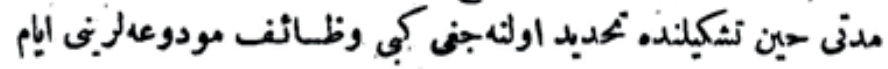

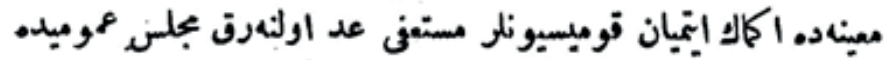

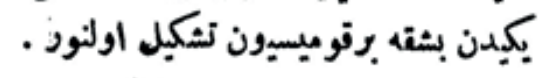

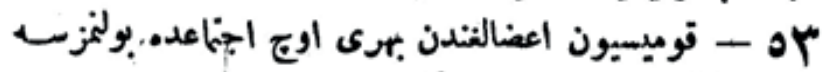

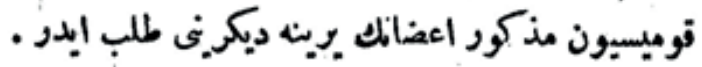

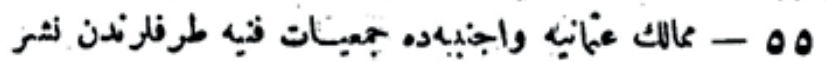

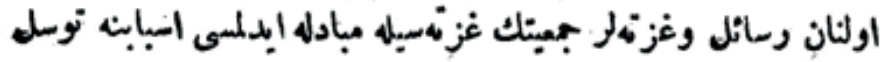

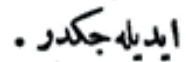


48- İctima-yı husûsîde vuku bulan müzakerât ve nutuklar hitam-1 mecliste kâtib-i umûmî tarafindan ahz olunur ve âzâlardan arzu edenler kâtib-i umûmîden talep ve ekseriyet-i ârâ ile neşr olunur.

49- Bazı mesailin amîkan tetkik veya ileride icab edecek mevâdd-1 mühimme üzerine bazı müzakere ve nizamnâmeler telif ve gazete neşretmek için bir veya müteaddit komisyonlar teşkili caiz olacak ve bu komisyonlara mahsus bir reis ve bir kâtib ve icabı kadar âzâlar meclis-i umumiyenin kararı üzerine tayin olunacaktır.

Ve bu nevi komisyonlar icabına göre tekessür eder.

50- Reis komisyonları icabına göre icçtimaya davet eyler ve mukarreratın derecâtını nazar-1 teftişten geçirir.

51- Komisyonlar peyderpey tahriren ve imzaları tahtında mukarreratlarını meclis-i idareye takdim ve meclis-i idare berây-1 tasdik meclis-i umûmiyeye arz eder.

52- Komisyonlara tevdi edilen vezaifin icra ve devam-1 müddet-i hîn-i teşkilinde tahdid olunacağı gibi vezaif-i mevdûlarını eyyam-ı muayyenede ikmal etmeyen komisyonlar müstafî addolunarak meclis-i umûmîde yeniden başka bir komisyon teşkil olunur.

53- Komisyon âzâlığından beheri üç ictimada bulunmazsa komisyon mezkûr âzânın yerine diğerini talep eder.

55-48 Memâlik-i Osmaniyede ve ecnebiyede cemiyet-i fenniye taraflarından neşrolunan resâil ve gazeteler cemiyetin gazetesiyle mübadele edilmesi esbabına tevessül edilecektir.

48 Numaralandırmada hata yapılmış. 53'den 55 numaraya geçiyor. Aslında nizmaname toplamda 68 maddeden müteşekkildir. 
إزوه كن - 0.7

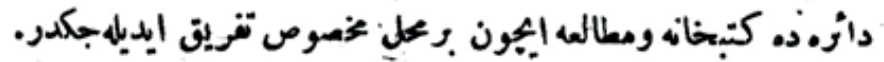

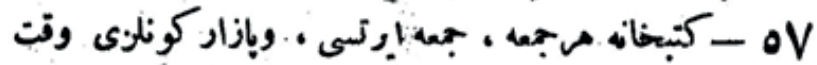

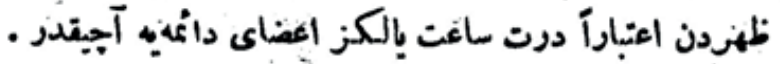

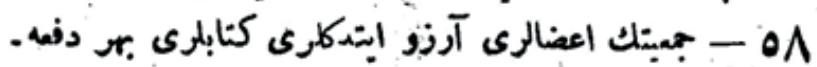

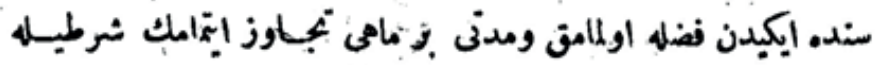

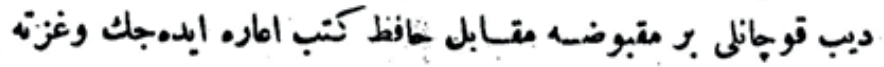

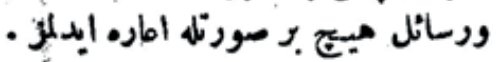

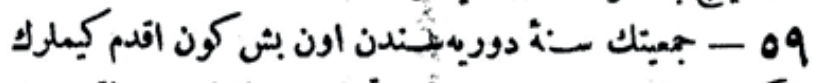

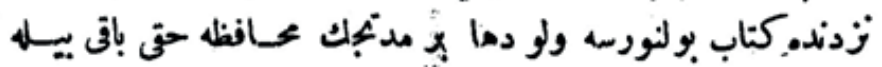

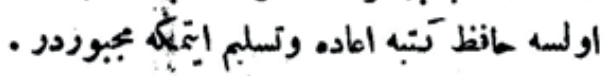

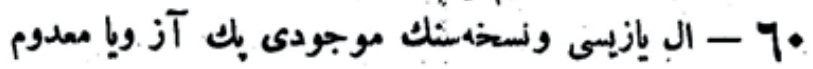

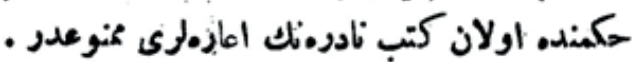
، 71

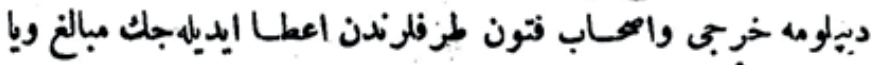

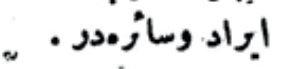

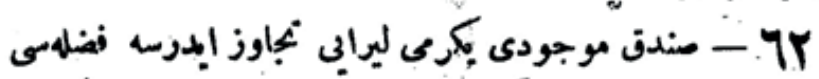

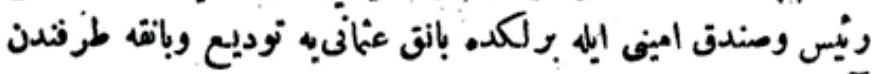

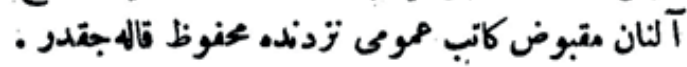

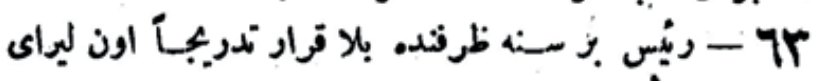

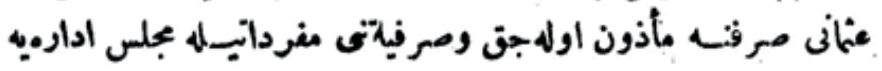

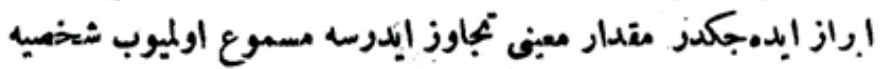

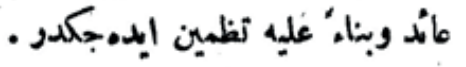


56- Cemiyetin kendisine mahsus bir dairesi olacak ve bu dairede kütüphane ve mütalaa için bir mahall-i mahsus tefrik edilecektir.

57- Kütüphane her Cuma, Cumartesi ve Pazar günleri vakt-i zuhrdan itibaren dört saat yalnız âzâ-yı dâimeye açıktır.

58- Cemiyetin âzâları arzu ettikleri kitapları beher defasında ikiden fazla olmamak ve müddeti bir mahı tecavüz etmemek şartıyla dip koçanlı bir makbuza mukabil hâfız-ı kütüb iâre edecek ve gazete ve resâil hiçbir suretle iâre edilmez.

59- Cemiyetin sene-i devriyesinden on beş gün akdem kimlerin nezdinde kitap bulunursa velev daha bir müddet için muhafaza hakkı baki bile olsa hafiz-1 kütübe iade ve teslim etmeğe mecburdur.

60- El yazısı ve nüshasının mevcudu pek az veya madûm hükmünde olan kütüb-i nadirenin iâreleri memnudur.

61- Menâbi'-i varidat cemiyet âzâlarının verdikleri mahiye, diploma harc1 ve eshâb-1 fünûn taraflarından itâ edilecek meblağ veya irad-1 vesairedir.

62- Sandık mevcudu yirmi lirayı tecavüz ederse fazlası reis ve sandık emini ile birlikte Bank-1 Osmaniye tevdi ve banka tarafindan alınan makbuz kâtib-i umûmî nezdinde mahfuz kalacaktır.

63- Reis bir sene zarfında bilâ-karar tedricen on lira-yı Osmanî sarfına mezun olacak ve sarfiyatını müfredatıyla meclis-i idareye ibraz edecektir miktar-1 muayyeni tecavüz ederse mesmû olmayıp şahsiye ait ve binaenaleyh tazmin edecektir. 


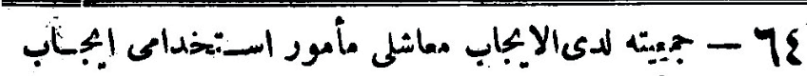

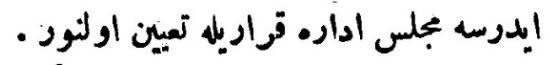

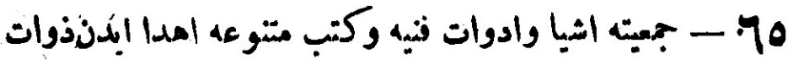

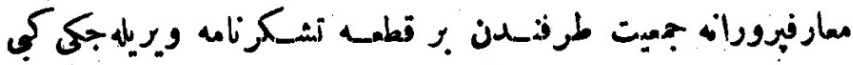

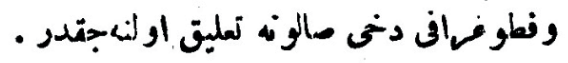

77

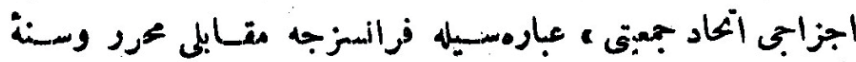

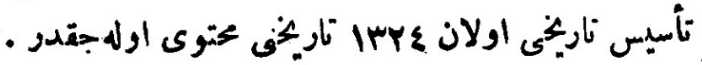

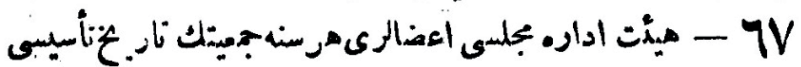

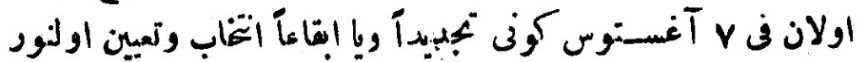

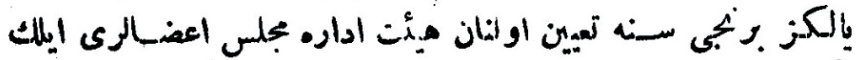

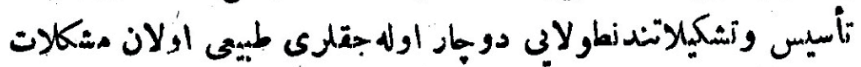

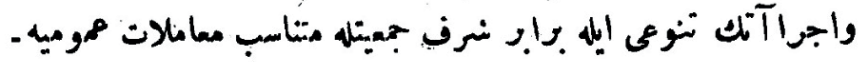

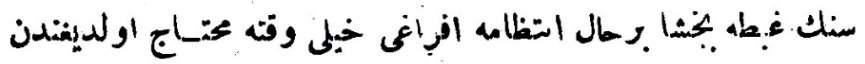

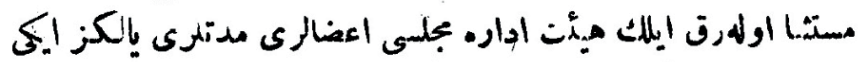

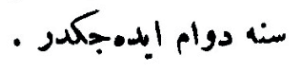

1

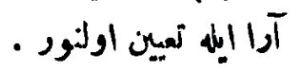

ولو 79 
$-18-$

64- Cemiyete lede'l-icâb maaşlı memur istihdamı icap ederse meclis-i idare kararıla tayin olunur.

65- Cemiyete eşya ve edevât-1 fenniye ve kütüb-i mütenevvia ihda eden zevat-1 maarif-perverâna cemiyet tarafından bir kıta teşekkürname verileceği gibi ve fotoğrafı dahi salona tâlik olunacaktır.

66- Cemiyetin bir adet resmî mührü olup "Osmanlı Eczacı İttihad Cemiyeti" ibaresiyle Fransızca mukabili muharrer ve sene-i tesis tarihi olan 1324 tarihini muhtevi olacaktır.

67- Heyet-i idare meclisi âzâları her sene cemiyetin tarih-i tesisi olan 7 Ağustos günü tecdiden veya ibkaen intihab ve tayin olunur. Yalnız birinci sene tayin olunan heyet-i idare meclis âzâları ilk tesis ve teşkilatından dolayı dûçar olacakları tabii olan müşkülat ve icraatın tenevvü ile beraber şeref-i cemiyetle mütenasip muamelât-1 umûmiyesinin gıbta-bahşa bir hal-i ittizâma ifrağı hayli vakte muhtaç olduğundan müstesna olarak ilk heyet-i idare meclisi âzâları müddetleri yalnız iki sene devam edecektir.

68- Heyet-i idare âzâları ayrı ayrı rey-i hafî̀ ve ekseriyet-i ârâ ile tayin olunur.

69- İşbu nizamname ekseriyet-i mutlaka ile üç sene sonra tebdil olunur. 


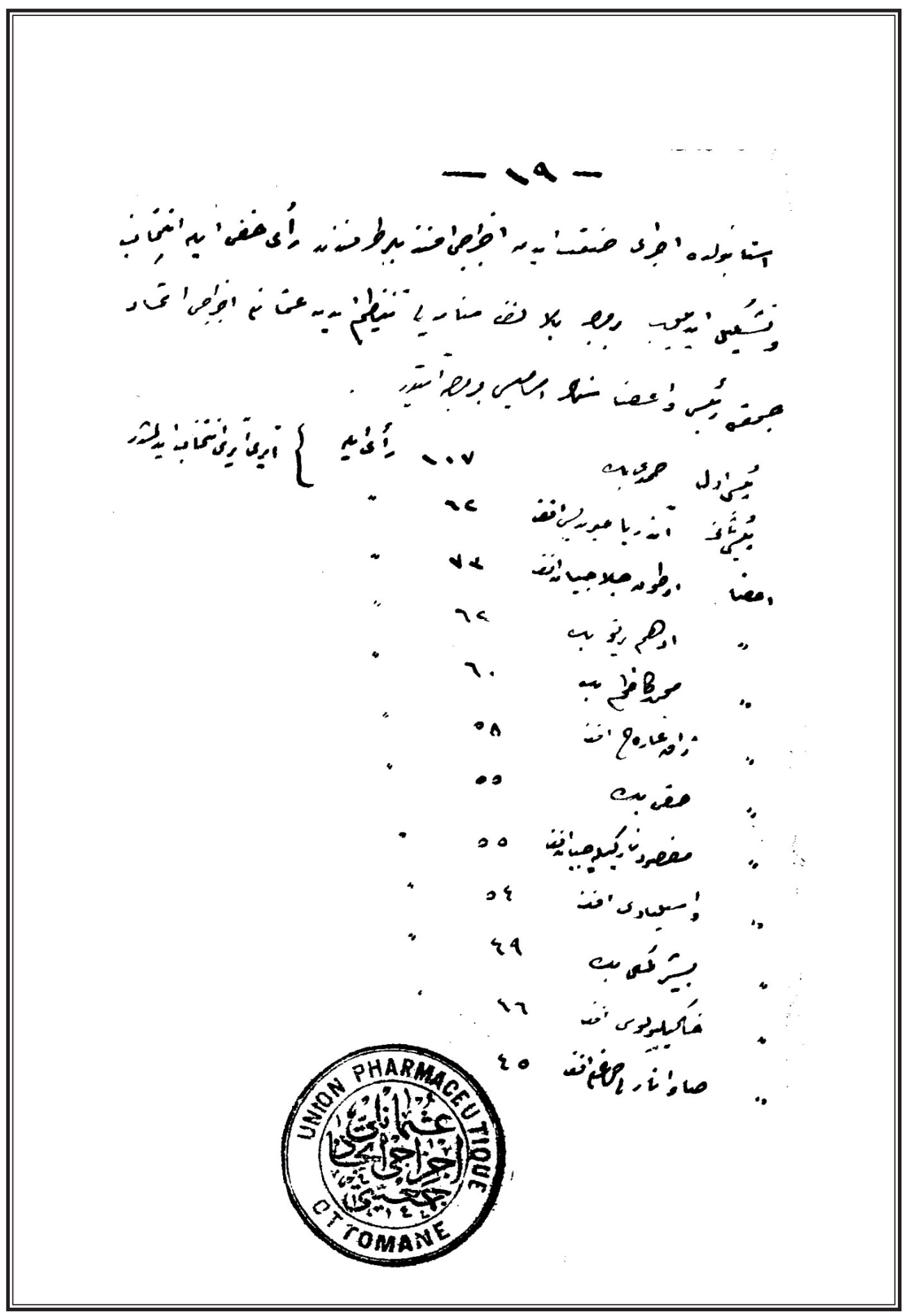


İstanbul'da icrâ-yı sanat eden eczacı efendiler tarafından rey-i hafî ile intihâb ve teşkil edilip ve ber-vech-i bâlâ nizamnameyi tanzim eden Osmanlı Eczacı İttihad Cemiyeti reisi ve âzâsının esâmîsi ber-vech-i âtîdir:

Reis-i Evvel Hamdi Bey, 107 rey ile. Ayrı ayrı intihab edilmişdir.

Reis-i Sânî Andrea Myrides Efendi, 62 rey

Âzâ Oton Cilaciyan Efendi, 73 rey

Âzâ Edhem Pertev Bey, 62 rey

Âzâ Mehmed Kâzım Bey, 60 rey

Âzâ Jak Garih Efendi, 58 rey

Âzâ Hakk1 Bey, 55 rey

Âzâ Maksud Nargileciyan Efendi, 55 rey

Âzâ Vasilyadis Efendi, 54 rey

Âzâ Beşir Kemal Bey, 49 rey

Âzâ Kalikiyopulos Efendi, 46 rey

Âzâ Sava Nazlığlu Efendi, 45 rey

(Mühür)

Osmanlı Eczacı İttihad Cemiyeti

Union Pharmaceutique Ottomane 
Hakem Değerlendirmesi: Dış bağımsız.

Çıkar Çatışması: Yazar çıkar çatışması bildirmemiştir.

Finansal Destek: Yazar bu çalışma için finansal destek almadığını beyan etmiştir.

Peer-review: Externally peer-reviewed.

Conflict of Interest: The author has no conflict of interest to declare.

Grant Support: The author declared that this study has received no financial support.

\section{KAYNAKÇA / BIBLIOGRAPHY}

\section{Arşiv Kaynakları / Archival Sources}

T.C. Cumhurbaşkanlığı Devlet Arşivleri Başkanlığı Başkanlık Osmanlı Arşivi (BOA). Dâhiliye Mektubî Kalemi (DH. MKT) 2673-3-3 H. 9 Zilkade 1326 [3 Aralık 1908].

BOA., DH. İrade (İD.) 126-1-1.; 126-1-2.; 126-1-3.; 126-1-4. H. 10 Ramazan 1328 [15 Eylül 1910].

BOA., DH. MKT. 1277-42-1 H. 12 Zilhicce 1326 [5 Ocak 1909].

Eyüp Talha Kocacık Arşivi (Sakarya)

\section{Basılı Kaynaklar / Printed Sources}

Baylav, Naşit. Eczacılık Tarihi. İstanbul: Yörük Matbaası, 1968.

Baytop, Turhan. "Osmanlı İmparatorluğu Döneminde Eczac1lık Cemiyetleri." Osmanlı İlmî ve Meslekî

Cemiyetleri. Yayına hazırlayan Ekmeleddin İhsanoğlu içinde, 143-154. İstanbul: İstanbul Üniversitesi

Edebiyat Fakültesi ve IRCICA, 1987.

—. Eczâhâne'den Eczane 'ye Türkiye'de Eczaneler ve Eczacılar (1800-1923). İstanbul: Bayer, 1995.

. Türk Eczacılık Tarihi Araştırmaları. İstanbul: Abdi İbrahim İlaç Sanayi ve Ticaret A.Ş., 2000.

Dersaadet Osmanlı Eczacı Ittihat Cemiyeti Nizamnamesi. Dersaadet: Mahmud Bey Matbaası, 1326.

El Hadj Hamdi. "Procédé nouveau pour la préparation des extraits fluides par lixiviation." Revue Médico-

Pharmaceutique 23, 1 (1910): 4.

Etker, Şeref. İkinci Meşrutiyetin Tabip Örgütleri. İstanbul: Libra Kitapçılık, 2017.

Farmakoloğ. "Hamdi Bey.” Farmakoloğ 3, 7-8 (1933): 707-708.

Farmakoloğ. "Mesleğimizin Türkiye'deki Tarihçesi." Farmakoloğ 3, 7 (1933): 696-706.

Groc, Gérard, ve İbrahim Çağlar. La Presse française de Turquie de 1795 à nos Jours - Histoire et Catalogue. Istanbul: Éditions Isis, 1985.

Kocacık, Eyüp Talha. “Edhem Pertev Bey Günü.” Eczacı 16, 181 (2020): 28-29.

“İstanbul ve Anadolu Eczanelerinde Mesai Saatleri ve Nöbet Uygulamaları: Bir Tarihçe.” Osmanlı Bilimi Araştırmaları 22, 1 (2021): 139-198.

“Türk Eczacıları Birliği’nden Önce Mesleki Örgütlenmenin Kısa Tarihi.” TEB Haberler 7 (2020): $7-13$.

Farmakoloğ Dergisinin Özetli Bibliyografyası ve Incelemesi. İstanbul: Eczacılık Tarihi Araştırma Derneği, 2016. 
Kocaer, Remzi. Türkiye Eczacılar Almană̆ 1949. İstanbul: Hüsnütabiat Basımevi, 1949.

“La Presse Musulmane.” Revue Du Monde Musulman 8, 5 (1909): 97-139.

“Ölenlerimiz.” Farmakoloğ 12, 1-4 (1942): 46-50.

Resimli Eczacı 13, 31 (Ağustos 1339/Ağustos 1923), kapak sayfas1.

Revue Médico- Pharmaceutique 24, 2 (1911): 19; 15, 4 (1902): 42; 15, 8 (1902): 91-92.

Rizzo, Alfred. Annuaire Oriental. Constatinople: Imprimerie de l'Annuaire Oriental, 1921.

Sandalcı, Mert. Belgelerle Türk Eczacılı̆̆l I. İstanbul: Dr. Nejat Eczacıbaşı Vakfi, 1997.

—. Belgelerle Türk Eczacıllğgl I-2. İstanbul: Dr. Nejat Eczacıbaşı Vakfi, 2002.

—. Belgelerle Türk Eczacıllğg II. İstanbul: Dr. Nejat Eczacıbaşı Vakfı, 1998.

—. Belgelerle Türk Eczacılığı II-2. İstanbul: Dr. Nejat Eczacıbaşı Vakfi, 2003.

—. Belgelerle Türk Eczacıllğı III. İstanbul: Dr. Nejat Eczacıbaşı Vakfı, 1999.

—. Belgelerle Türk Eczacıllğı III-2. İstanbul: Dr. Nejat Eczacıbaşı Vakfı, 2005.

—. Belgelerle Türk Eczacılı̆̆ IV. İstanbul: Dr. Nejat Eczacıbaşı Vakfı, 2000.

—. Belgelerle Türk Eczacıllğg IV-2. İstanbul: Dr. Nejat Eczacıbaşı Vakfı, 2001.

—. Belgelerle Türk Eczacıliğg V. İstanbul: Dr. Nejat Eczacıbaşı Vakfı, 2006.

“Société Pharmaceutique." Le Moniteur Oriental, 25 Ağustos 1908, 3. 
